\title{
Early animal management strategies during the Neolithic of the Konya Plain, Central Anatolia: integrating micromorphological and microfossil evidence
}

Article

Accepted Version

Garcia-Suarez, A., Portillo, M. and Matthews, W. (2020) Early animal management strategies during the Neolithic of the Konya Plain, Central Anatolia: integrating micromorphological and microfossil evidence. Environmental Archaeology: the Journal of Human Palaeoecology, 25 (2). pp. 208-226. ISSN 1461-4103 doi:

https://doi.org/10.1080/14614103.2018.1497831 Available at https://centaur.reading.ac.uk/78060/

It is advisable to refer to the publisher's version if you intend to cite from the work. See Guidance on citing.

To link to this article DOI: http://dx.doi.org/10.1080/14614103.2018.1497831

Publisher: Maney Publishing

All outputs in CentAUR are protected by Intellectual Property Rights law, including copyright law. Copyright and IPR is retained by the creators or other copyright holders. Terms and conditions for use of this material are defined in 
the End User Agreement.

www.reading.ac.uk/centaur

\section{CentAUR}

Central Archive at the University of Reading

Reading's research outputs online 


\title{
Early animal management strategies during the Neolithic of the Konya Plain, Central Anatolia: integrating micromorphological and microfossil evidence
}

\author{
Aroa García-Suárez, Marta Portillo and Wendy Matthews \\ Department of Archaeology, School of Archaeology, Geography and Environmental \\ Sciences, University of Reading, Reading, UK
}

\begin{abstract}
This paper examines the contribution of microscopic multi-proxy approaches to the study of early husbandry practices and animal diet by integrated micromorphological, phytolith, and calcitic dung spherulite analyses of midden deposits at the three neighbouring Neolithic sites of Boncuklu (9th-8th millennium cal BC), Pınarbaşı (7th millennium cal BC) and Çatalhöyük (8th6th millennium cal BC) in the Konya Plain, Central Turkey.

The results reveal considerable chronological and contextual variation in human-animal interrelations in open areas between different communities and sites. At Boncuklu, middens display well-defined areas where phytoliths and substantial accumulations of omnivore faecal matter low in spherulite content have been identified. By contrast, open spaces at the Late Neolithic campsite of Pınarbaş1 comprise large concentrations of herbivore dung material associated with neonatal ovicaprine remains from spring birthing. Here, the deposits represent repeated dungburning events, and include high concentrations of dung spherulites and phytoliths from wild grasses, and leaves and culms of reeds that, we suggest here, derive from fodder and fuel sources. Late middens at Çatalhöyük are characterised by thick sequences derived from multiple fuel burning events and rich in ashes, charred plants, articulated phytoliths - mainly from the husk of cereals, as well as the leaves and stems of reeds and sedges - and omnivore/ruminant coprolites, the abundance of the latter declining markedly in the latest levels of occupation.
\end{abstract}

The application of this integrated microscopic approach to open areas has contributed to unravelling the complexity of formation processes at these sites, providing new insights into herding practices, diet, and the ecological diversity of Neolithic communities in Central Anatolia.

Keywords: husbandry; coprolite; midden; micromorphology; phytoliths; dung spherulites; Neolithic; Anatolia 


\section{Introduction}

Central Anatolia, situated within the distribution zone of major domesticated animal species, namely cattle, pig and ovicaprines (Martin et al. 2002), and having been identified as the origin of a number of plant domesticates (Özkan et al. 2002), is a region of key importance for understanding the development of Neolithic innovations and their spread from the Near East to other geographic territories. However, in spite of the numerous early settlements found in this area dating to $c a$. 9700-6000 BC (Baird 1996, 2005, 2012; Baird et al. 2018), the Central Anatolian Neolithic has tended to be viewed from the perspective of one or two large sites, with Çatalhöyük (7100-6200 cal BC) and its exceptionally complex wall art and architecture occupying a prominent place in archaeological investigations within this regional setting (Hodder 2007). Recent excavations at the early agricultural site of Boncuklu (8300-7800 cal BC), $9.5 \mathrm{~km}$ north of Çatalhöyük, and the Late Neolithic occupation of the Pınarbaşı rockshelter in the Konya Plain (6500-6000 cal BC) have contributed to place the large, aggregated community at Çatalhöyük in a broader historical and contemporary context, providing new insights into the emergence and development of Neolithic lifeways in this part of the world (Baird et al. 2011; 2012; 2018, Figure 1).

This paper examines the micromorphological and microfossil evidence of animal management strategies at these three sites through the analysis of in situ stratigraphic sequences in middens and open areas. Faecal remains and penning deposits were observed in constructed pens and abandoned buildings within the settlement at Çatalhöyük in previous geoarchaeological research (Barański et al. 2015; Matthews 2005; Shillito et al. 2011). Excavations at Boncuklu revealed the occurrence of suspected omnivore coprolites in open areas, while herbivore dung deposits were identified macroscopically in middens at Pınarbaşı. This study focuses solely on open 
spaces, as these are contexts in which potential animal enclosures can be detected, as observed in multiple ethno-archaeological studies around the world (Elliott et al. 2015; Portillo et al. 2014, 2017; Shahack-Gross et al. 2004; Tsartsidou et al. 2008). Further, middens and open areas constitute ideal contexts for the study of husbandry and associated practices through the identification of animal faecal matter as, in Near Eastern Neolithic settlements, middens are often constituted by accumulated layers of discarded materials derived from both industrial and domestic activities, including livestock dung used as fuel and as building material (Shahack-Gross 2017).

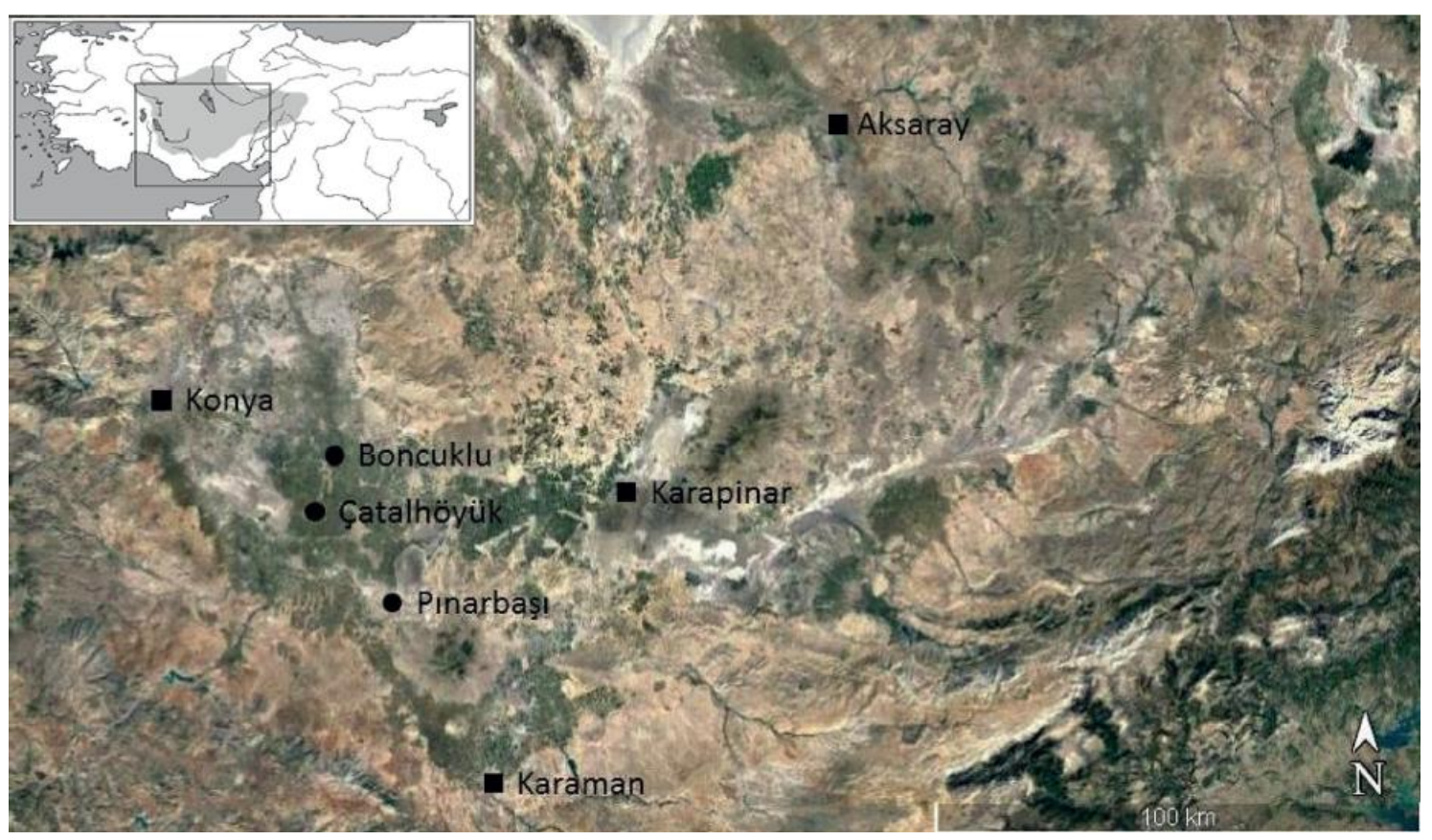

Figure 1: Map of south-central Turkey showing the three study sites (circles) in relation to the main cities (squares) in the region.

At Boncuklu, zooarchaeological studies documented the exploitation of cattle and, to a lesser extent, boar/pig, with sheep and goat skeletal remains present in very low proportions (Baird et al 2012; 2018). The wild/domestic status of these ovicaprines remains obscured based on morphometric grounds. However, stable isotope results show a high $\delta^{15} \mathrm{~N}$ value for some caprine individuals, which appears to indicate an increased consumption of $\mathrm{C}_{4}$ plants growing in the saline marsh areas of the plain, away 
from the natural habitat of these animals, and interpreted as the result of human control (Baird et al. 2018). In contrast to the Boncuklu faunal assemblage, sheep/goat constitutes the dominant taxon at both Pınarbaşı and Çatalhöyük, with a sharp increase in caprine herding occurring during the latest period of occupation of Çatalhöyük (Baird et al. 2011; Russell et al. 2013). This paper examines accumulations of suspected omnivore coprolites and ruminant dung identified macroscopically in midden deposits located within these three settlements to investigate the nature, composition, depositional pathways, and taphonomy of faecal remains as evidence of herding practices by early agricultural communities.

The integrated geoarchaeological approach applied in this study combines micro-contextual information of depositional conditions through thin-section micromorphology with opal phytolith and calcitic dung spherulite data for the identification of faecal matter as a critical indicator of animal management, concepts of space and health within a settlement. This approach has proven successful in previous studies of enclosures and archaeological animal dung (Akeret and Rentzel 2001; Kühn et al. 2013; Shahack-Gross 2011). At the Central Anatolian site of Aşıklı Hüyük, in Cappadocia, integrated zooarchaeological and geoarchaeological research comprising micromorphological and phytolith analyses has resulted in the documentation of the occurrence of caprine herding by 8300 cal BC (Stiner et al. 2014). In fact, the nature of middens at these Central Anatolian sites, with areas of fine stratification in which individual layers and components are difficult to resolve by eye (Baird et al. 2012; Shillito and Matthews 2013; Yeomans 2005), makes the application of microstratigraphic methods highly suitable to examine the complex history of these sequences at high-resolution. Therefore, this research aims to: 
- Identify and characterise faecal remains in middens at Boncuklu, Çatalhöyük, and Pınarbaşı, distinguishing between herbivore, omnivore, and potentially human coprolites through the simultaneous observation of their composition and depositional contexts in thin-section with extracted phytolith and spherulitic materials.

- Explore early husbandry practices through the micro-stratigraphic examination of suspected penning deposits, zones of waste disposal, and discarded dung fuel in open areas.

- Investigate landscape use and animal diets at the study sites through the analysis of phytolith microfossils embedded in coprolites.

While several authors have suggested the existence of a distinctive local path in the development and adoption of Neolithic innovations in the Konya Plain (Baird 2012; Baird et al. 2018; Özdoğan 1999), the micro-contextual comparison of the geoarchaeological evidence for husbandry, diet, and concepts of space at Boncuklu, Çatalhöyük, and Pınarbaşı, places us in a unique position to test this hypothesis and to explore continuity and change in the animal management strategies adopted by neighbouring communities in this region over a wide temporal frame.

\section{Study area}

An extensive area of south-central Anatolia is occupied by the Great Konya Basin, an inland drainage plateau that extends over one million hectares and has an average altitude of 1000 m above sea-level (Kuzucuoğlu, Parish, and Karabiyikoglu 1998). The volcanic massifs of Karacadağ and Karadağ define two small sub-basins on which human settlements were established after the waters of the Pleistocene lake receded due to increased evaporation caused by warmer climatic conditions in this region (Boyer, Roberts, and Baird 2006). One of these sub-basins is the Konya Plain, located towards 
the west of the Great Konya Basin and surrounded by the Taurus Mountains to the south and the Anatolides to the north and west (Driessen and de Meester 1969; Inoue, Saito, and Naruse 1998). As rivers flowed into the marl plain formed by the dried out Pleistocene lake, alluvial sediments were deposited across the Konya Plain, resulting in the creation of wetland habitats and alluvial landforms. The largest of these formations is the Çarşamba alluvial fan, that covers an area of approximately $474 \mathrm{~km}^{2}$ (Roberts et al. 1999) and on which a number of early Neolithic settlements are located, including Boncuklu and Çatalhöyük. By contrast, the site of Pınarbaşı is situated towards the centre of the Konya Basin, approximately $25 \mathrm{~km}$ to the southeast of Çatalhöyük, occupying the base of a cliff at the foothills of the volcanic massif of Karadağ.

\section{Boncuklu}

The mound settlement of Boncuklu stands $2 \mathrm{~m}$ above current plain level and covers an area of approximately 1 ha. This site, with an occupation span of $c a .8500-7500 \mathrm{cal} \mathrm{BC}$, was originally situated in a reed-dominated wetland/marshland and steppe mosaic habitat that included regularly flooded areas as well as permanent water bodies (Baird et al. 2012).

Archaeological excavations at Boncuklu started in 2006, involving the opening of a number of trenches, or excavation areas, on the mound (Figure 2). This study focuses on Area M, situated in the centre of this settlement and comprising midden layers accumulated under different depositional conditions, generally containing dense quantities of animal bones, carbonised and silicified plant materials, and artefacts (Baird, Fairbairn, et al. 2013). The samples analysed in this study were collected from the south-eastern corner of this excavation area, to investigate a sequence of finely 
laminated deposits rich in ashes, articulated phytoliths, and suspected coprolitic materials extending over approximately $3 \mathrm{~m}^{2}$.

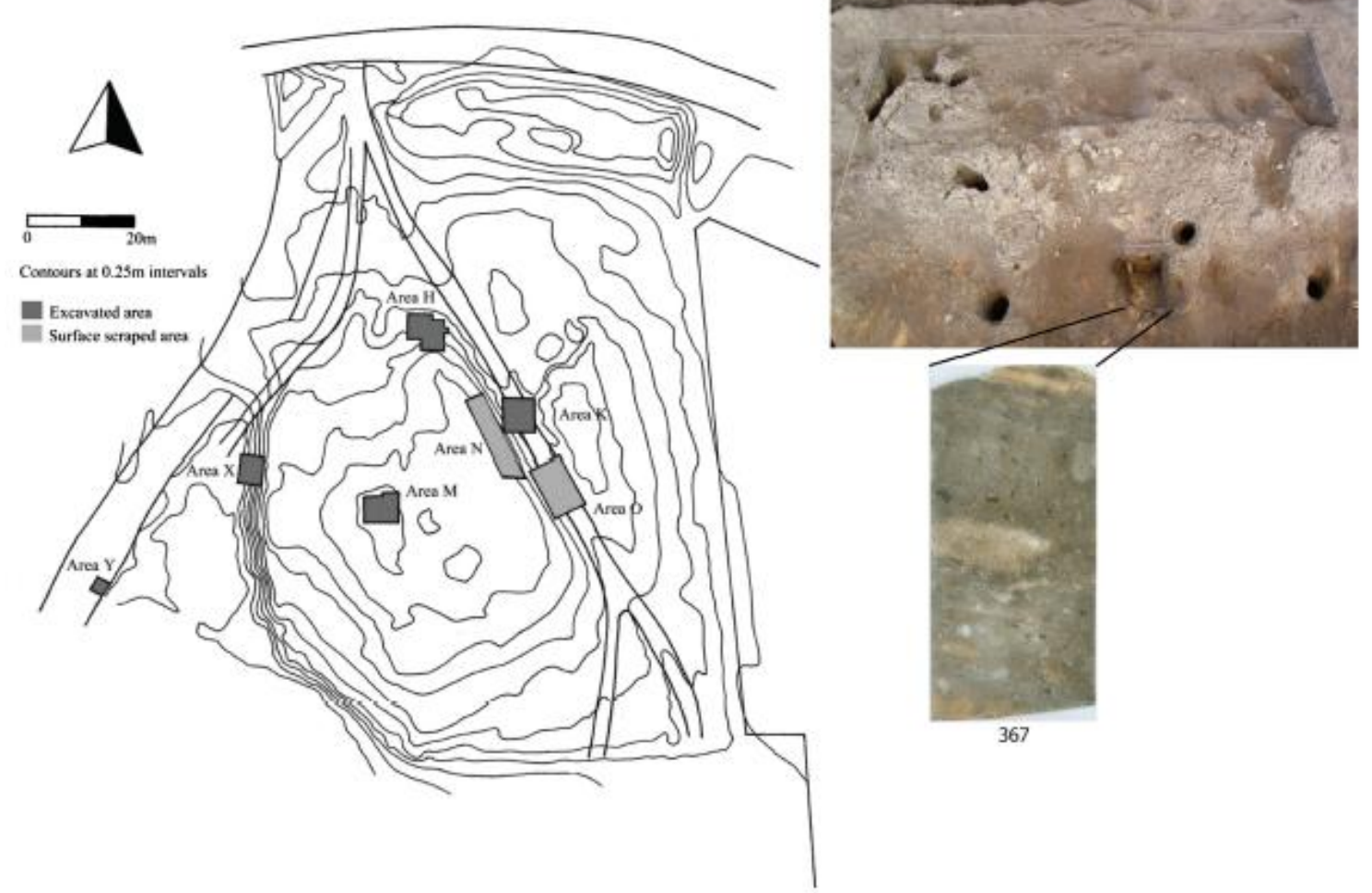

Figure 2: Site plan of the Boncuklu mound displaying excavated areas and view of south-eastern corner of Area M, from where block sample 367 was collected. Source: Baird et al. 2012: 239.

\section{Pınarbaşı}

The site of Pınarbaş1 is located northwest of the Karadağ volcanic mountains, on the slope of a limestone hill. Palaeoenvironmental studies indicate the existence of a nearby lake and marsh at the time of its earliest occupation, as well as the presence of almond and pistachio trees in its surrounding landscape (Asouti 2003; Baird, Asouti, et al. 2013).

This study focuses on deposits from Area B, accumulated within the shell of a habitation structure that was set against the limestone cliff face and dated to $c a$. 65006000 cal BC (Watkins 1996, Figure 3). Here, zooarchaeologists identified large quantities of sheep remains that include foetuses and neonates, pointing to a strong 
seasonal signature for spring (Baird et al. 2011). Body-part representation appears to indicate that complete animal carcasses were butchered on site, a fact that prompted the interpretation of Area B as a specialised campsite used by a mobile herding and hunting group during the 7th millennium cal BC, contemporary with the late Neolithic occupation at Çatalhöyük East (Mellaart Levels V-I).

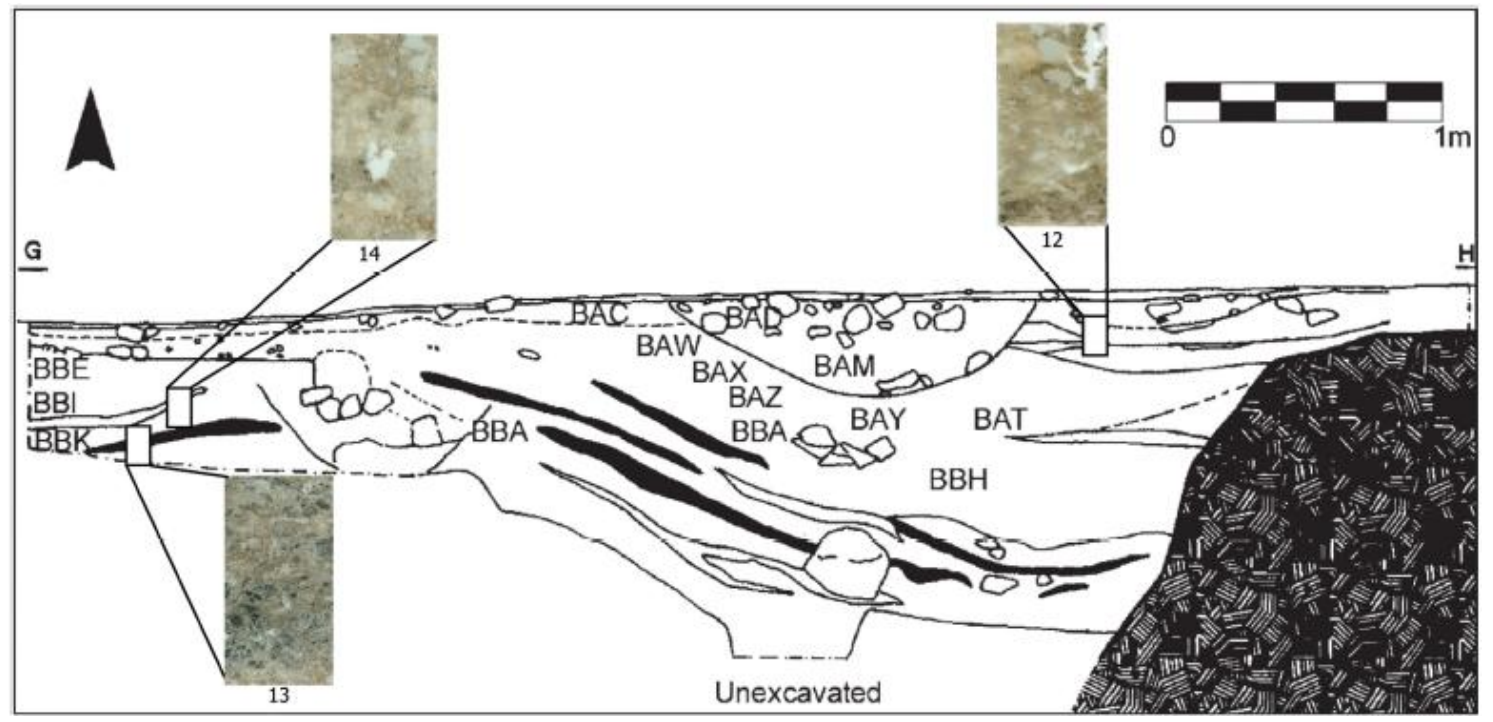

Figure 3: Field section of Area B at Pınarbaşı displaying micromorphology block sampling locations. Source: D. Baird (modified after excavation archives).

\section{Çatalhöyük}

The UNESCO World Heritage site of Çatalhöyük is located along the eastern bank of the former Çarşamba river, which runs nowadays through a rural channel bordering the settlement. The site comprises two low hills, the Neolithic East Mound, that dates approximately from 7100 to 6000 cal BC (Bayliss et al. 2015), and the West Mound, occupied in the Early Chalcolithic period.

The samples analysed in this paper were collected from the Late Neolithic occupation levels of the site, exposed in the GDN (Gdańsk) and TPC (Team Poznań Connection) Areas, situated on the south-western slope of the East Mound (Figure 4). 
Fieldwork in the GDN Area, that covers to a great extent the former Mellaart A and B Areas, began in 2012 with the goal of examining previously exposed structures in this part of the settlement (Barański 2013). Micromorphological samples were collected from Space 544, a narrow midden between Building 111 and Building 141 (Barański 2014). Works in the TPC Area, dated to $c a$. 6500-5950 cal BC, started in 2012 in order to examine social and economic transformations towards the end of the Neolithic at this site (Marciniak 2015). Samples were collected from two unexcavated midden sequences visible in the western sections of the excavation trenches 1 and 2, corresponding to Mellaart levels III-I. The open spaces sampled in these two excavation areas displayed finely stratified midden deposits consisting of ashes and charred plant materials that include traces of suspected herbivore and possible omnivore dung, with localised bioturbated areas visible macroscopically in the field.

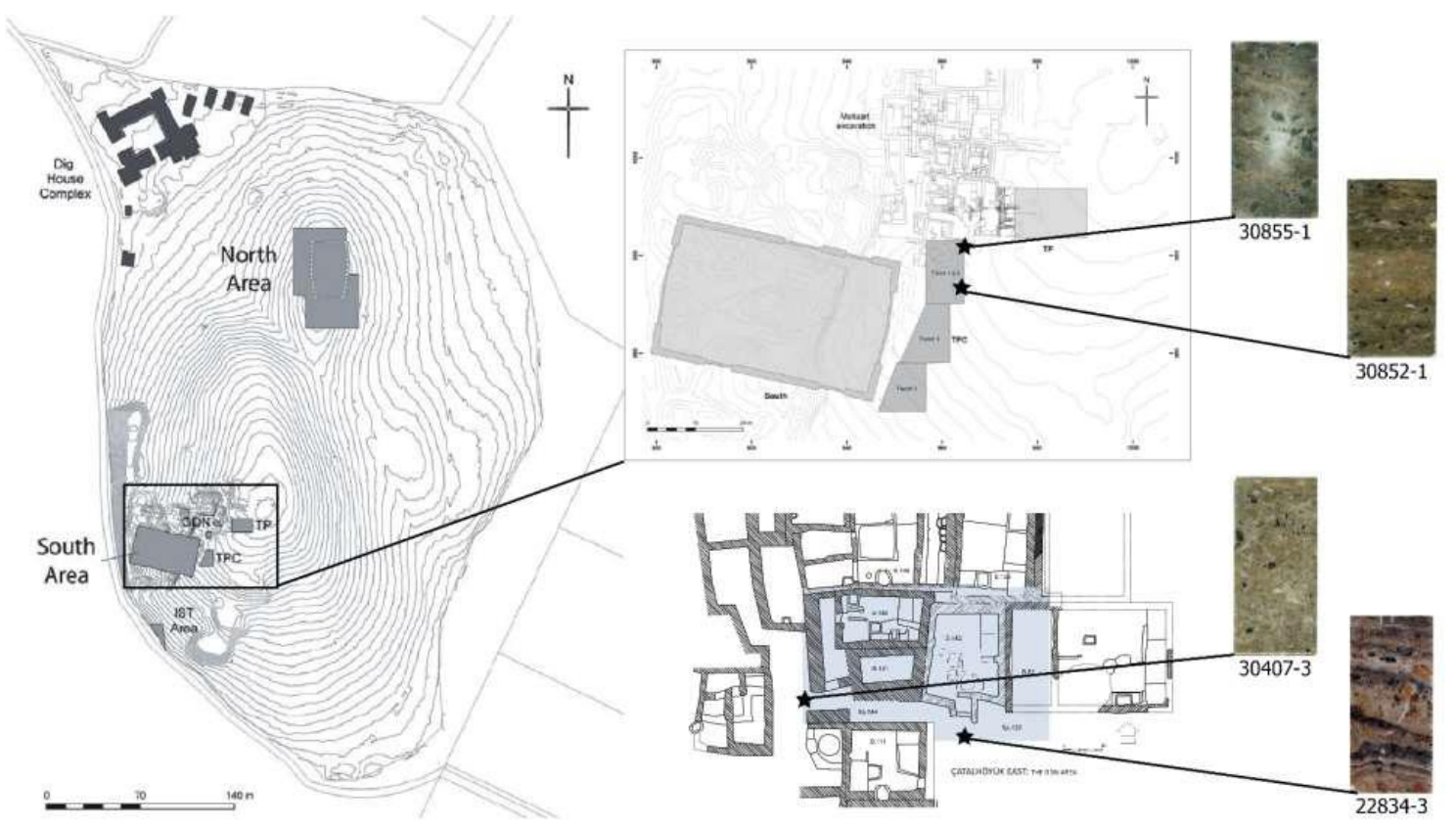

Figure 4: Site plan of Çatalhöyük East displaying main excavation areas (left), and detailed view of TPC (top centre) and GDN (botton centre) areas showing micromorphology sampling locations. Source: C. Mazzucato for Çatalhöyük Research Project and M. Barański (GDN Area). 


\section{Materials and methods}

Eight sediment blocks were collected from midden and open contexts at the three study sites and manufactured into large-format $(14 \times 7 \mathrm{~cm})$ micromorphological slides: 367 from Boncuklu; 12, 13, 14 from Pınarbaş1; and 22834-3, 30407-3, 30852-1, and 308551 from Çatalhöyük (Table 1). Of these blocks, seven were systematically sub-sampled prior to thin-section manufacture for integrated micromorphological, phytolith and faecal spherulite studies. In total, thirteen spot sediment samples from Boncuklu (samples 243, 244, 354 ss1-2, 367 ss1-4, and 394 ss1-5, coded as BK for reference), nine from Pınarbaş1 (PB samples 6, 12 ss1,2,4, 13 ss1-4, and 14 ss1) and ten from Çatalhöyük (CH samples 22834-3 ss2-4, 30852-1 ss2-4, and 30855-1 ss2-6) were selected for phytolith and dung spherulite studies. While some of these samples constitute hand-picked suspected coprolitic materials identified during fieldwork at these sites (243, 244, and 394 ss1-3 at Boncuklu, and 6 at Pınarbaş1), the majority of these samples were collected from fine layers and suspected faecal materials, as well as from associated contexts situated above and below these coprolitic remains, visible in the face of the micromorphological blocks. This sampling strategy has thus enabled a direct comparison between quantitative microfossil data and micromorphological observations.

\section{Micromorphological analysis}

After collection in the field, the sediment blocks were carefully packed and transported in rigid boxes to avoid any physical disturbances that could alter the morphology of the samples. Once in the laboratory, the blocks were oven dried at $40^{\circ} \mathrm{C}$ with epoxy resin under vacuum, and hardened at $70^{\circ} \mathrm{C}$ for 18 hours. After cooling, a slice of approximately $1 \mathrm{~cm}$ thickness was cut from the face of interest of each of the hardened 
block samples using a diamond saw, and subsequently trimmed. Each cut slice was then impregnated on a hot plate at $40^{\circ} \mathrm{C}$ with a mixture of Araldite epoxy resin, temporarily mounted on glass media, and placed in a Brot grinder-polisher to obtain perfectly planed sample surfaces before permanent mounting to a glass slide. Samples were then grinded to a thickness of $30 \mu \mathrm{m}$ and coverslipped.

\begin{tabular}{|c|c|c|c|c|}
\hline Site & Area & Sample & Field description & Basis for micromorphological sampling \\
\hline \multirow[t]{2}{*}{ Boncuklu } & M & 367 & $\begin{array}{l}\text { Massive midden deposits showing } \\
\text { abundant coprolites of suspected } \\
\text { omnivore origin. }\end{array}$ & $\begin{array}{l}\text { To study the nature and composition of } \\
\text { the suspected coprolites, as well as their } \\
\text { depositional pathways. }\end{array}$ \\
\hline & TPC & $30852-1$ & $\begin{array}{l}\text { Homogeneous, thick deposits with } \\
\text { frequent orangish inclusions. } \\
\text { Multiple fine ashy layers rich in } \\
\text { charred plant remains. }\end{array}$ & $\begin{array}{l}\text { To explore the nature of the orangish } \\
\text { inclusions in these massive layers. } \\
\text { To investigate composition and formation } \\
\text { processes of finely laminated ash } \\
\text { sequences. }\end{array}$ \\
\hline \multirow[t]{2}{*}{ Çatalhöyük } & \multirow{2}{*}{ GDN } & $30407-3$ & $\begin{array}{l}\text { Ashy midden deposits displaying } \\
\text { abundant plant charred materials. }\end{array}$ & $\begin{array}{l}\text { To identify components and formation } \\
\text { processes of homogeneous midden } \\
\text { deposits. }\end{array}$ \\
\hline & & $22834-3$ & $\begin{array}{l}\text { Finely laminated midden sequence } \\
\text { with suspected herbivore dung. }\end{array}$ & $\begin{array}{l}\text { To examine the nature of suspected dung } \\
\text { layers in finely stratified midden } \\
\text { sequences. }\end{array}$ \\
\hline \multirow{3}{*}{ Pinarbasi } & \multirow{3}{*}{ B } & 12 & $\begin{array}{l}\text { Discarded fuel material containing } \\
\text { abundant calcitic ashes. }\end{array}$ & $\begin{array}{l}\text { To explore the range of fuel sources and } \\
\text { activity residues occurring in open areas. }\end{array}$ \\
\hline & & 13 & $\begin{array}{l}\text { Thick accumulated deposits rich in } \\
\text { charred plant remains. }\end{array}$ & $\begin{array}{l}\text { To study the origin and deposition of } \\
\text { homogeneous midden deposits. }\end{array}$ \\
\hline & & 14 & $\begin{array}{l}\text { Accumulated units with pale } \\
\text { yellow inclusions rich in } \\
\text { phytoliths. }\end{array}$ & $\begin{array}{l}\text { To investigate the nature of thick midden } \\
\text { deposits with suspected herbivore dung. }\end{array}$ \\
\hline
\end{tabular}

Table 1: Summary of micromorphological samples analysed and field descriptions.

Micromorphological slides were analysed using a Leica DMLP microscope at magnifications from $\times 25$ to $\times 400$ under plane-, cross-polarised, and fluorescent light. 
Photomicrographs were captured using a DFC420 camera, and enhanced through the LeicaV2.3 image analysis software. The samples were described using the standard terminology developed by Stoops (2003).

\section{Phytolith analysis}

Phytoliths were extracted following the method of Katz et al. (2010). A weighed aliquot of $\sim 40 \mathrm{mg}$ of dried sediment was treated with $50 \mu \mathrm{l}$ of a volume solution of $6 \mathrm{~N} \mathrm{HCl}$. Phytoliths were concentrated using $450 \mu \mathrm{l} 2.4 \mathrm{~g} / \mathrm{ml}$ sodium polytungstate solution $\left[\mathrm{Na}_{6}\left(\mathrm{H}_{2} \mathrm{~W}_{12} \mathrm{O}_{40}\right)\right]$. Microscope slides were mounted with $50 \mu \mathrm{l}$ of material. A minimum of 200 phytoliths with diagnostic morphologies were examined at $\times 200$ and $\times 400$ using a Leica DMEP optical microscope. Digital images were obtained using a Leica DFC420 camera and a DMPL optical microscope. The estimated phytolith numbers per gram of sediment are related to the initial sample weight and allow quantitative comparisons to be made between the samples.

Phytoliths that were unidentifiable, mainly due to the presence of surface pitting and etching caused by dissolution, were recorded and listed in Table 2 as weathered morphotypes. Multicellular structures (multi-celled or interconnected phytoliths) were also recorded. Morphological identification was based on modern plant reference collections and standard literature (Brown 1984; Piperno 2006; Mulholland and Rapp 1992; Rosen 1992; Twiss 1992; Twiss, Suess, and Smith 1969). Where appropriate, we have followed the International Code for Phytolith Nomenclature (Madella, Alexandre, and Ball 2005). Table 3 lists the main morphologies identified with correspondence to the ICPN morphotypes and plants or plant parts from which they derive based on modern reference studies (Albert and Weiner 2001; Albert et al. 2008, 2011, 2016; Portillo et al. 2014; Tsartsidou et al. 2007). 


\begin{tabular}{|c|c|c|c|c|c|c|c|}
\hline $\begin{array}{l}\text { Site/ } \\
\text { sample }\end{array}$ & Area & $\begin{array}{l}\text { Field } \\
\text { sample } \\
\text { n. }\end{array}$ & $\begin{array}{l}\text { Phytoliths 1 } \\
\text { g of } \\
\text { sediment }\end{array}$ & $\begin{array}{l}\text { Phytoliths } \\
\text { weathering } \\
\text { (\%) }\end{array}$ & $\begin{array}{l}\text { Multicelled } \\
\text { phytoliths } \\
(\%)\end{array}$ & $\begin{array}{l}\text { Spherulites 1 } \\
\text { g of } \\
\text { sediment }\end{array}$ & Field description \\
\hline$\overline{\text { BK-1 }}$ & $\mathrm{M}$ & 243 & 4.400 .000 & 7.1 & 34.9 & 0 & $\begin{array}{l}\text { Suspected omnivore } \\
\text { coprolite }\end{array}$ \\
\hline BK-2 & M & 244 & 3.600 .000 & 9.1 & 35 & 0 & $\begin{array}{l}\text { Suspected omnivore } \\
\text { coprolite }\end{array}$ \\
\hline BK-3 & M & $354 \mathrm{ss} 1$ & 6.100 .000 & 8.3 & 30 & 30.000 & $\begin{array}{l}\text { Suspected omnivore } \\
\text { coprolite }\end{array}$ \\
\hline BK-4 & M & $354 \mathrm{ss} 2$ & 5.700 .000 & 6.1 & 35.6 & 0 & $\begin{array}{l}\text { Suspected omnivore } \\
\text { coprolite }\end{array}$ \\
\hline BK-5 & M & $367 \mathrm{ss} 1$ & 3.200 .000 & 5.6 & 37.1 & 0 & $\begin{array}{l}\text { Suspected omnivore } \\
\text { coprolite }\end{array}$ \\
\hline BK-6 & M & 367 ss2 & 6.700 .000 & 5.9 & 37.1 & 0 & $\begin{array}{l}\text { Ashy deposit rich in } \\
\text { phytoliths }\end{array}$ \\
\hline BK-7 & M & $367 \mathrm{ss} 3$ & 7.300 .000 & 5.7 & 31.9 & 36.000 & $\begin{array}{l}\text { Suspected omnivore } \\
\text { coprolite }\end{array}$ \\
\hline BK-8 & M & 367 ss 4 & 6.400 .000 & 6.4 & 35.1 & 6.000 & $\begin{array}{l}\text { Ashy deposit rich in } \\
\text { phytoliths }\end{array}$ \\
\hline BK-9 & M & 394 ss1 & 900.000 & 5.5 & 31.6 & 18.000 & $\begin{array}{l}\text { Suspected omnivore } \\
\text { coprolite }\end{array}$ \\
\hline BK-10 & M & 394 ss2 & - & - & - & 0 & $\begin{array}{l}\text { Suspected omnivore } \\
\text { coprolite }\end{array}$ \\
\hline BK-11 & M & $394 \mathrm{ss} 3$ & - & - & - & 30.000 & $\begin{array}{l}\text { Suspected omnivore } \\
\text { coprolite }\end{array}$ \\
\hline BK-12 & M & $394 \mathrm{ss} 4$ & 8.300 .000 & 5.5 & 34 & 6.000 & $\begin{array}{l}\text { Layer of articulated } \\
\text { phytoliths }\end{array}$ \\
\hline BK-13 & M & 394 ss5 & 7.600 .000 & 6.7 & 36.8 & 18.000 & Ashy midden deposit \\
\hline PB-1 & $\mathrm{B}$ & 6 & 4.700 .000 & 6.7 & 5.9 & 1.200 .000 & $\begin{array}{l}\text { Suspected herbivore } \\
\text { coprolite }\end{array}$ \\
\hline PB-2 & $\mathrm{B}$ & $12 \mathrm{ss} 1$ & 4.400 .000 & 3.7 & 9.2 & 3.160 .000 & $\begin{array}{l}\text { Accumulation of } \\
\text { herbivore dung }\end{array}$ \\
\hline PB-3 & $\mathrm{B}$ & $12 \mathrm{ss} 2$ & - & - & - & 4.900 .000 & $\begin{array}{l}\text { Mixed ash deposit with } \\
\text { faecal aggregates }\end{array}$ \\
\hline PB-4 & $\mathrm{B}$ & $12 \mathrm{ss} 4$ & 6.300 .000 & 6.6 & 5.4 & 3.300 .000 & $\begin{array}{l}\text { Accumulation of charred } \\
\text { dung }\end{array}$ \\
\hline PB-5 & $\mathrm{B}$ & 13 ss 1 & 5.600 .000 & 6.1 & 8.6 & 3.600 .000 & $\begin{array}{l}\text { Discard deposit rich in } \\
\text { burnt dung }\end{array}$ \\
\hline PB-6 & $\mathrm{B}$ & $13 \mathrm{ss} 2$ & 4.500 .000 & 5.9 & 8.8 & 1.900 .000 & $\begin{array}{l}\text { Accumulation of burnt } \\
\text { herbivore dung }\end{array}$ \\
\hline PB-7 & $\mathrm{B}$ & 13 ss 3 & 800.000 & 7.6 & 8.6 & 24.000 & $\begin{array}{l}\text { Accumulation of charred } \\
\text { plant remains }\end{array}$ \\
\hline PB-8 & $\mathrm{B}$ & $13 \mathrm{ss} 4$ & 1.100 .000 & 5.7 & 29.7 & 300.000 & Mixed charred deposit \\
\hline PB-9 & $\mathrm{B}$ & $14 \mathrm{ss} 1$ & - & - & - & 4.000 .000 & Charred herbivore dung \\
\hline $\mathrm{CH}-1$ & GDN & $\begin{array}{l}22834-3 \\
\text { ss2 }\end{array}$ & 9.100 .000 & 2.6 & 25.2 & 0 & $\begin{array}{l}\text { Mixed midden deposit } \\
\text { with phytoliths }\end{array}$ \\
\hline $\mathrm{CH}-2$ & GDN & $\begin{array}{l}22834-3 \\
\text { ss3 }\end{array}$ & 8.700 .000 & 4.6 & 49 & 80.000 & $\begin{array}{l}\text { Accumulated unit rich in } \\
\text { charred plants }\end{array}$ \\
\hline $\mathrm{CH}-3$ & GDN & $\begin{array}{l}22834-3 \\
\text { ss } 4\end{array}$ & 7.900 .000 & 6.4 & 39.1 & 940.000 & $\begin{array}{l}\text { Suspected herbivore } \\
\text { dung }\end{array}$ \\
\hline $\mathrm{CH}-4$ & TPC & $\begin{array}{l}30852-1 \\
\text { ss2 }\end{array}$ & 4.900 .000 & 10.8 & 29.5 & 0 & Ashy midden deposit \\
\hline CH-5 & TPC & $\begin{array}{l}30852-1 \\
\text { ss3 }\end{array}$ & 3.100 .000 & 10.7 & 11.9 & 0 & $\begin{array}{l}\text { Suspected omnivore } \\
\text { dung }\end{array}$ \\
\hline $\mathrm{CH}-6$ & TPC & $\begin{array}{l}30852-1 \\
\text { ss } 4\end{array}$ & 3.300 .000 & 8 & 15.6 & 6.000 & $\begin{array}{l}\text { Mixed midden deposit } \\
\text { rich in ashes }\end{array}$ \\
\hline
\end{tabular}




\begin{tabular}{|c|c|c|c|c|c|c|c|}
\hline $\mathrm{CH}-7$ & TPC & $\begin{array}{l}30855-1 \\
\text { ss2 }\end{array}$ & 7.500 .000 & 5 & 44.6 & 6.000 & $\begin{array}{l}\text { Mixed unit with abundant } \\
\text { charred plants }\end{array}$ \\
\hline CH-8 & TPC & $\begin{array}{l}30855-1 \\
\text { ss } 4\end{array}$ & 7.800 .000 & 4.8 & 48.6 & 0 & $\begin{array}{l}\text { Midden deposit rich in } \\
\text { charred woods }\end{array}$ \\
\hline CH-9 & TPC & $\begin{array}{l}30855-1 \\
\text { ss5 }\end{array}$ & 3.300 .000 & 7.6 & 21.6 & 0 & $\begin{array}{l}\text { Mixed unit with } \\
\text { suspected coprolites }\end{array}$ \\
\hline $\mathrm{CH}-10$ & TPC & $\begin{array}{l}30855-1 \\
\text { ss6 }\end{array}$ & 6.800 .000 & 6.9 & 39 & 18.000 & $\begin{array}{l}\text { Laminated phytoliths and } \\
\text { calcitic ashes }\end{array}$ \\
\hline
\end{tabular}

Table 2: Description of samples and main quantitative phytolith and dung spherulite results from Boncuklu (BK), Pınarbaşı (PB) and Çatalhöyük $(\mathrm{CH})$, in central Anatolia.

\begin{tabular}{|c|c|c|}
\hline Phytolith morphotype & ICPN equivalents & Attribution \\
\hline Bulliform (fan and pillow shape) & $\begin{array}{l}\text { Cuneiform bulliform cell and } \\
\text { Parallepipedal bulliform cell }\end{array}$ & Grass leaves \\
\hline Cylindroid & Cylindric & Monocotyledonous \\
\hline Ellipsoid psilate or rugulate & & Dicotyledonous wood/bark \\
\hline Epidermal appendage hair/ awn type & Hair cell mesophyll & $\begin{array}{l}\text { Dicot leaves/ grass } \\
\text { inflorescences }\end{array}$ \\
\hline Elongate psilate or rugulate & Elongate & Monocots \\
\hline Epidermal appendage hair base & Hair base & Dicot leaves \\
\hline Epidermal appendage papillae & Papillae cell & Grass inflorescences \\
\hline Epidermal appendage prickle & Prickle & Grass leaves \\
\hline Hat shape & & Cyperaceae \\
\hline Irregular psilate or rugulate & & Wood/bark dicots \\
\hline Long cell echinate & Elongate echinate long cell & Grass inflorescences \\
\hline Long cell dendritic & Dendritic & Grass inflorescences \\
\hline Long cell polylobate & Trapeziform polylobate & Grass leaves \\
\hline $\begin{array}{l}\text { Multicellular structures of long cells } \\
\text { echinate or dendritic (with papillae or } \\
\text { short cells) }\end{array}$ & $\begin{array}{l}\text { Silica skeleton of echinate or } \\
\text { dendritic long cells }\end{array}$ & Grass inflorescences \\
\hline $\begin{array}{l}\text { Multicellular structures of long cell } \\
\text { dendriforms (with stomata) }\end{array}$ & $\begin{array}{l}\text { Silica skeleton of dendritic cells } \\
\text { with stomate }\end{array}$ & Grass leaves/stems \\
\hline $\begin{array}{l}\text { Multicellular structures of long cells } \\
\text { psilate }\end{array}$ & Silica skeletons of elongate cells & Monocot leaves \\
\hline Multicellular structure polyhedral & Silica skeleton favose & Dicot leaves \\
\hline Parallelepiped blocky & Parallelepipedal & Wood/bark dicots \\
\hline $\begin{array}{l}\text { Parallelepiped elongate and elongate } \\
\text { facetated }\end{array}$ & Elongate & Monocots \\
\hline Parallelepiped thin psilate or rugulate & Tabular/ Trapeziform & Monocots \\
\hline Platelet & & Dicot leaves \\
\hline Short cell bilobate & Bilobate short cell & Grasses \\
\hline Short cell saddle & Saddle & Grasses \\
\hline Short cell rondel & Rondel & Grasses \\
\hline
\end{tabular}


Table 3: List of the most common phytolith morphotypes identified in the samples and their plant attribution based on reference collections and standard literature.

\section{Dung spherulite analysis}

The methods used in this study are similar to those proposed by Canti (1999). Approximately $1 \mathrm{mg}$ of dried sediment was mounted on a microscope slide with Entellan New from Merck. Spherulites identified in a known number of randomly chosen fields were counted at $\times 400$ magnification under an optical microscope DMEP with crossed polarised light (XPL). Both dung spherulites and estimated phytolith concentrations per gram of sediment were then plotted and compared to reference ethnoarchaeological datasets of modern dung remains and livestock dung-products that have followed similar quantitative approaches (Gur-Arieh et al. 2013; Portillo, Valenzuela, and Albert 2012; Portillo et al. 2014, 2017; Tsartsidou et al. 2008).

\section{Results}

\section{Micromorphological observations}

The microstratigraphy of the midden sequence in the south-eastern corner of Area M at Boncuklu, examined in sample 367 , appears to indicate a relatively slow but continuous accumulation of organic materials in this part of the settlement (Figure 5). Coprolites constitute approximately $40 \%$ of these otherwise very homogeneous contexts, a concentration that has not been found anywhere else in this settlement. Two types of faecal aggregates have been distinguished, according to micromorphological characteristics and components. Type 1 consists of up to $70 \%$ crushed and digested bones, at least some of which appear to belong to bird or amphibian species. 10-15\% of 
these faecal remains is formed by phytoliths and other plant remains. These coprolites, that measure up to $8 \mathrm{~cm}$ in length, do not contain faecal spherulites. By contrast, Type 2 appear as dense, optically isotropic orange masses of phosphatic material embedding up to $20 \%$ of partially digested bones, $2 \%$ herbaceous phytoliths, and up to $15 \%$ charred plant flecks. These faecal pellets are generally smaller and more disaggregated than those classified as Type 1, ranging between 0.8 and $4 \mathrm{~cm}$ in size.


Figure 5: Open space in Area $\mathrm{M}$ at Boncuklu; a) midden deposits showing abundant accumulations of suspected omnivore coprolites, visible as orange lenses displaying strong parallel orientations in the top part of the section; b) photomicrograph of Type 1 omnivore faecal aggregate in thin-section, showing abundant digested bones, PPL; c) photomicrograph of Type 2 omnivore faecal inclusion in thin-section, displaying a denser, highly phosphatic groundmass, PPL.

Other anthropogenic components found in these open contexts at Boncuklu include very fragmented charred plant remains (5-20\% abundance), herbaceous phytoliths (5-15\%), burnt bones (5-10\%), shell fragments (2-5\%), and approximately 5\% dispersed calcitic ashes. All these inclusions have been found randomly oriented and distributed, which points to their secondary deposition in this midden as fuel/food refuse and discarded rake-outs. In addition, trampling indicators are not evident in this sequence, which rules out the hypothesis of boar/pig penning as the origin of the 
important concentration of faecal aggregates found in this area of the settlement. Preliminary GC-MS analyses of bile acids and sterols extracted from coprolite samples from this midden point towards a human origin for these remains (I. Bull, pers. comm.), so it is possible that this area actually constituted a latrine where faecal waste, in addition to burnt discards from fire activities, accumulated.

Midden deposits at Pınarbaşı are substantially minerogenic, especially when compared to similar contexts from Boncuklu and Çatalhöyük. Herbivore dung rich in phytoliths and calcium carbonate spherulites is ubiquitous in samples 12 and 14 , and in the upper part of sample 13 (approximately 50-70\% abundance), although occurring mixed with other materials, such as dispersed ashes, charred plants, bone fragments, and limestone clasts detached from the rockshelter, suggestive of dumping and redeposition. As at Boncuklu, the absence of trampling indicators in these layers, such as compaction, massive or laminar microstructures, finely layered bedding, strong horizontal orientation of embedded inclusions, and crushing of bone, shell and charcoal fragments (Matthews et al. 1996; Milek 2012; Rentzel et al. 2017), dismisses the interpretation of these open sequences as penning areas. Rather, the occurrence of charred and partially calcined faecal matter strongly associated with calcitic ashes and darkened spherulites (Canti and Nicosia 2018) points to the frequent use of dung as fuel at $7^{\text {th }}$ millennium Pınarbaşı. By contrast, the earlier sequence in sample 13 comprises accumulations rich in plant materials (40-50\% abundance), predominantly wood charcoal and smaller fragments of charred plants. A wide variety of arboreal sources has been observed in these layers, particularly Pistacia and Amygdalus, possibly available near the site (Asouti 2003). These deposits are dominated by large $(c a .1 \mathrm{~cm})$ fragments of tree bark, likely derived from branches and twigs, occurring in association with 
charred herbivore dung ( $20 \%$ abundance), indicating the use of mixed fuel sources

(Figure 6).
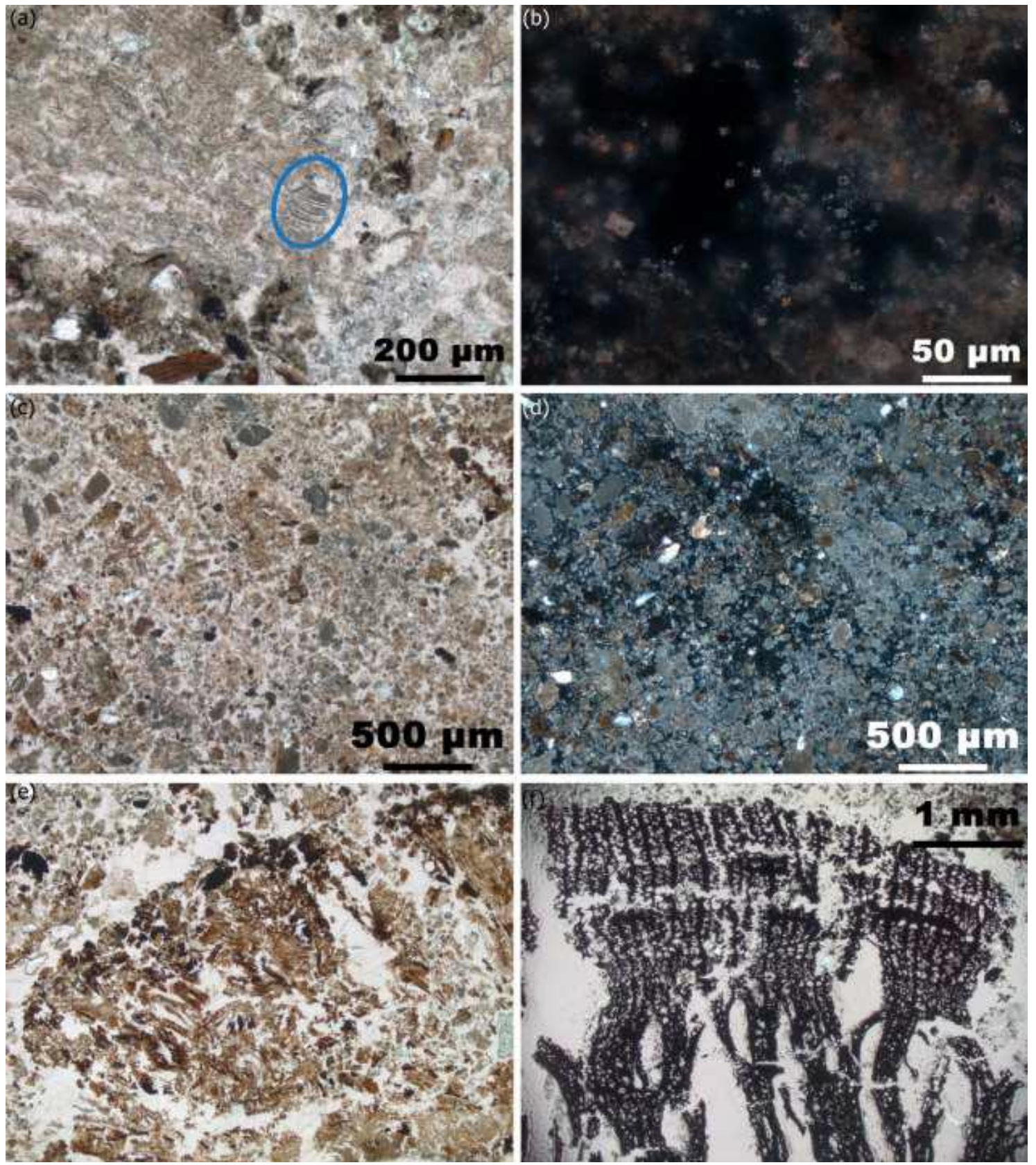

Figure 6: Photomicrographs of components in midden layers at Pınarbaşı: a) calcined dung pellet displaying abundant inclusions of bulliform siliceous plant remains (circled in blue), PPL; b) calcareous spherulites, XPL; c) dung-derived ashes, PPL; d) same as c, XPL; e) charred herbivore dung aggregate, PPL; and f) fragment of wood charcoal, PPL.

At Çatalhöyük, previous microstratigraphic research on midden contexts from the TP Area, immediately to the north of the current TPC Area and close to the top of 
the East Mound, highlighted the lack of extensive fine stratification in this part of the settlement when compared to middens from earlier occupation levels, in addition to a higher incidence of post-depositional alterations in the form of gypsum crystallisation and bioturbation (Shillito 2011a; Shillito and Matthews 2013). However, the research conducted here has detected finely laminated midden stratigraphy in a number of field sections in the GDN and TPC Areas, especially in Mellaart Levels II-I, representing a rapid build-up of materials in this later period.

GDN Area sample 30407-3, collected from Space 544 and assigned to Mellaart Levels II-I (6200-6000 cal BC), comprises massive and homogeneous midden deposits rich in bioarchaeological inclusions, such as charred plants (25-40\% abundance), bone and shell fragments (ca. 10\%), and obsidian flakes (1\%), but devoid of faecal matter (Figure 7). Abundant fragments of Ulmus, Quercus and Juniperus, tree species present in the local landscape and commonly found within the settlement as preferred firewoods (Asouti 2005), have been identified in these layers. The mixed nature and random orientation and distribution of the components forming these units suggest sedimentation by accumulation of plant fuel discards. In contrast, sample 22834-3, collected from the latest Neolithic layers in the same open space, displays a finely laminated midden sequence constituted by rapidly accumulated layers of calcitic ashes and charred plant matter in parallel orientation (in situ deposition), alternating with mixed deposits rich in randomly oriented and distributed minerogenic aggregates, siliceous plants, and highly burnt faecal matter. Up to $40 \%$ of these heterogeneous strata are formed by re-deposited dung aggregates displaying abundant disaggregated phytoliths and, to a lesser extent, darkened spherulites, indicative of burning temperatures between $500-700^{\circ} \mathrm{C}(\mathrm{Canti}$ and Nicosia 2018) (Figure 7). 

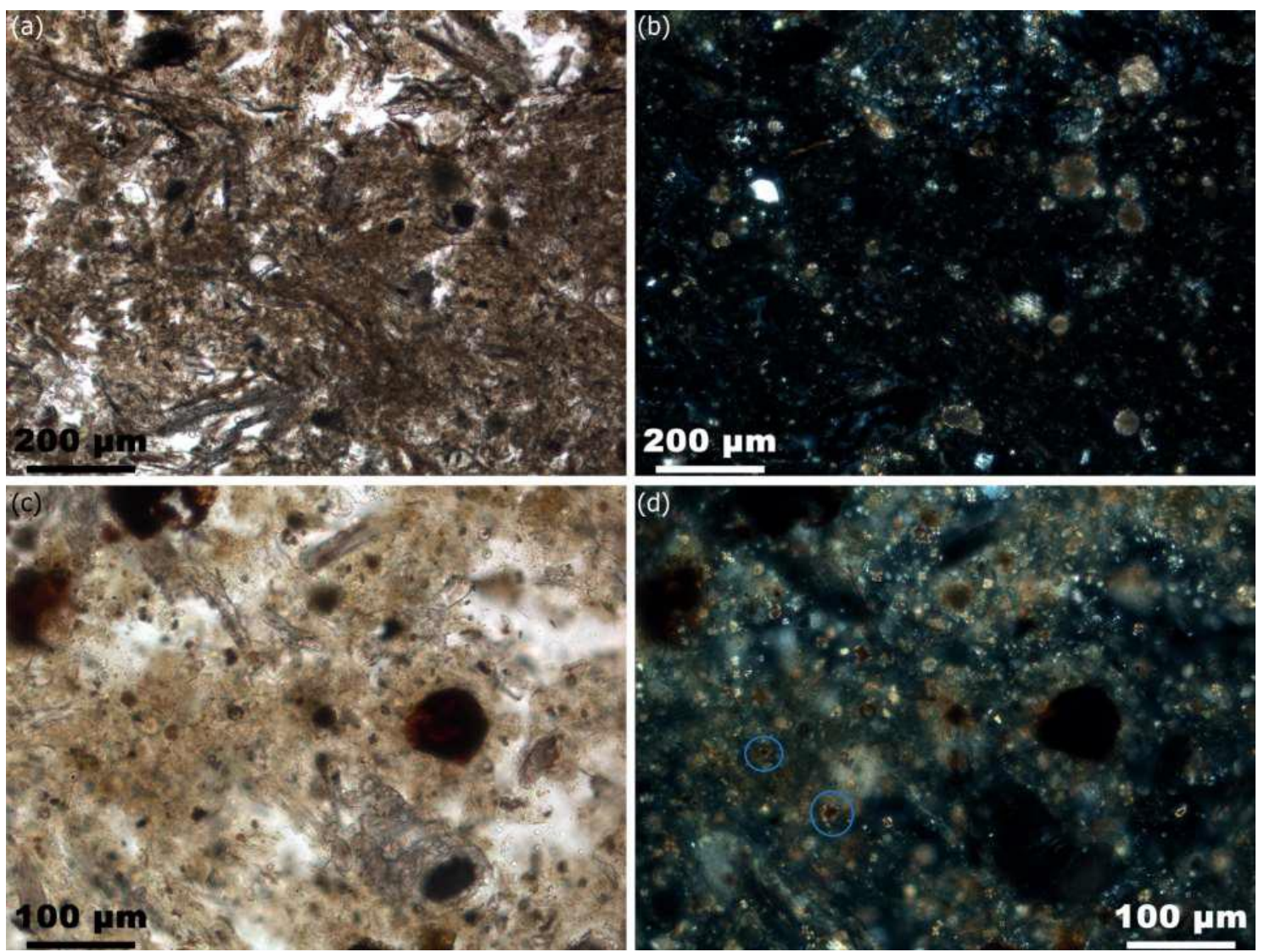

Figure 7: a) Photomicrograph of highly burned herbivore dung aggregate at Çatalhöyük, displaying abundant phytolith inclusions, PPL; and b) same as a, showing very few dung spherulites due to taphonomic processes leading to the disintegration of these calcitic microfossils caused by high burning temperatures, XPL; c) photomicrograph of charred dung pellet, PPL; d) same as c, displaying few calcitic spherulites that appear to be transitioning towards darkened spherulites (circled in blue), XPL.

The TPC Area midden deposits in sample 30852-1, assigned to Mellaart Levels IV-III, are characterised by their considerable thickness, which ranges between 3 and 5 $\mathrm{cm}$, and high minerogenic fraction, formed by gradually deposited sediments of various origins and rounded aggregates derived from sweeping activities. These features, in addition to the marked compositional homogeneity of the deposits, point to slow rates of accumulation. Further, the dark greyish brown colour of these layers appears to derive from the presence of charred organic matter associated with iron oxihydrates. Approximately $10 \%$ faecal aggregates of suspected herbivore origin have been detected in these strata, which include variable proportions of burned plants (ca. 20-50\% 
abundance) dominated by Ulmus and Juniperus charcoal, and large bone fragments ( $c a$. $5-15 \%$ ) up to $6 \mathrm{~mm}$ in length (Figure 8).
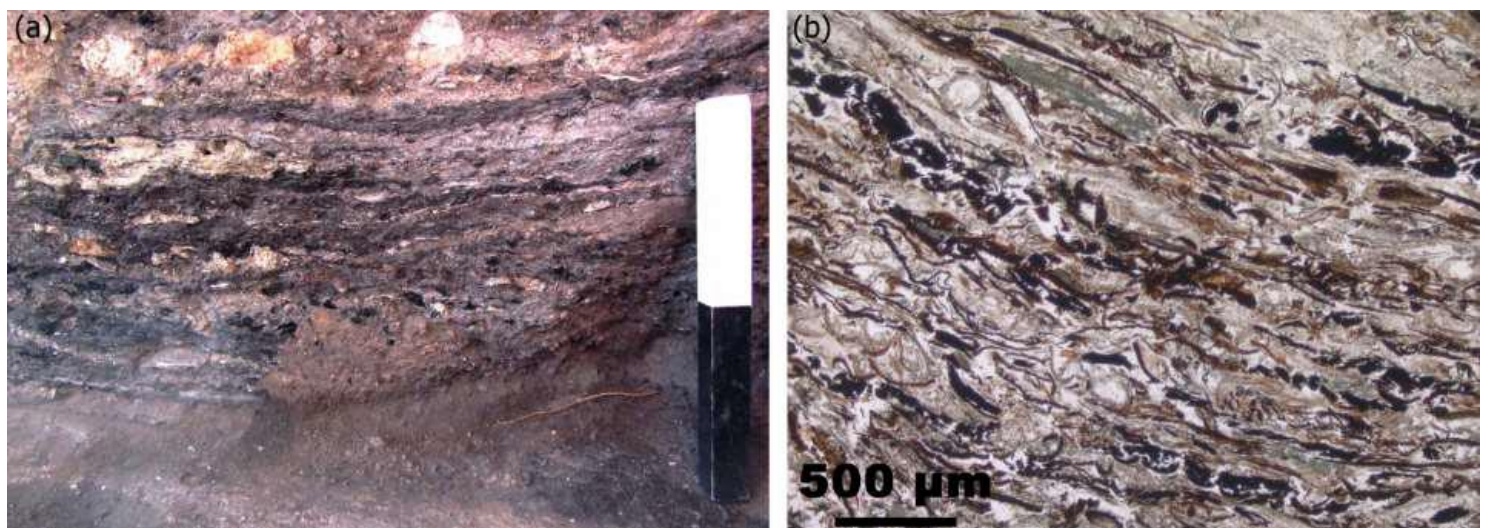

Figure 8: a) Block sample 30855-1 collected from TPC Area at Çatalhöyük formed by multiple fine layers of ash and charred plant materials; and b) photomicrograph of fine midden stratigraphy displaying in situ decay of burned plant matter, PPL.

A marked shift in depositional patterns has been detected by Mellaart level II-I in this excavation area. The latest midden deposits in the TPC sequence, observed in sample 30855-1, are characterised by their extremely high organic content, a result of the multiple ash and plant microlaminations that constitute these contexts. Situated within two Late Neolithic buildings, the major components of these deposits are calcitic ashes (5-40\% abundance), herbaceous phytoliths (10-60\%), and Juniperus charcoal (10$50 \%$ ), all of which display strong parallel orientations, although substantial trampling or compaction indicators have not been found in this sequence. This suggest that this area was likely used for in situ open-air fires, activities that resulted in a rapid build-up of fuel materials of plant origin, as the good preservation of ashes and conjoined reed phytoliths suggests. However, due to their proximity to the topsoil, a large proportion of these midden layers show evidence of bioturbation in the form of root action associated with gypsum re-crystallisation, channel voids caused by microfauna, and pedogenesis. Faecal aggregates are again completely absent from this microstratigraphic sequence. 


\section{Phytolith concentrations}

Phytoliths are very abundant in all samples, ranging between 0.8 and 9 million per $1 \mathrm{~g}$ of sediment (Table 2). The low proportion of weathered phytoliths, together with the presence of multi-celled phytoliths (multicellular or anatomically connected) in all the samples (over 40\%), appears to be indicative of the good state of preservation of the assemblages, although these factors are also dependent on a range of taphonomic processes and laboratory procedures (Cabanes and Shahack-Gross 2015; Cabanes, Weiner and Shahack-Gross 2011; Jenkins 2009; Madella and Lancelotti 2012; Shillito 2011b). The phytolith morphological results point towards a general similarity between all studied samples, with dominance of monocotyledonous phytoliths (74-95\% abundance, Figure 9a) including grasses from the Pooideae subfamily, reeds (Arundinoideae) and sedges (Cyperaceae). Phytoliths from the leaves and culms of grasses, including prickles, bulliforms, stomata, and short cells, were dominant in most of the samples (Figures $9 \mathrm{~b}$ and 10a). Certain diagnostic morphotypes, such as dendriforms and papillae cells from the inflorescences of grasses, occur in greater proportions in specific assemblages, rather than being ubiquitous throughout all the deposits examined (Figures 9b and 10b). The presence of these morphotypes, generally considered as delicate or fragile cells (Cabanes et al. 2011), in addition to the low proportions of weathered phytoliths in the samples, are again significant indicators of the good state of preservation of these assemblages. 




Figure 9. (a) Relative abundances of phytoliths obtained from Boncuklu (BK), Pınarbaş1 (PB) and Çatalhöyük $(\mathrm{CH})$ samples. (b) Anatomical origin of grass phytoliths.

\section{Dung spherulite concentrations}

Calcitic dung spherulites have been identified in most of the samples analysed, although in highly variable amounts. The midden deposits of the Late Neolithic campsite of Pınarbaşı have yielded the largest spherulite concentrations (over 3.1-4.9 million spherulites/g sediment, Table 2, Figure 10c), including darkened spherulites identified in the micromorphological thin-sections (Figure 7d). These microfossils are scarce, or even absent, in both the Boncuklu and Çatalhöyük assemblages, possibly indicating variable production by different species, or dissolution of these calcitic micro-remains (Canti 1999; Gur-Arieh et al. 2013, 2014). Dung spherulite concentrations at these two 
sites range between $6.000-80.000$ spherulites/g sediment, with the only exception of sample $\mathrm{CH}-3$, that yielded substantially higher numbers (0.9 $\mathrm{m}$ spherulites/g sediment).
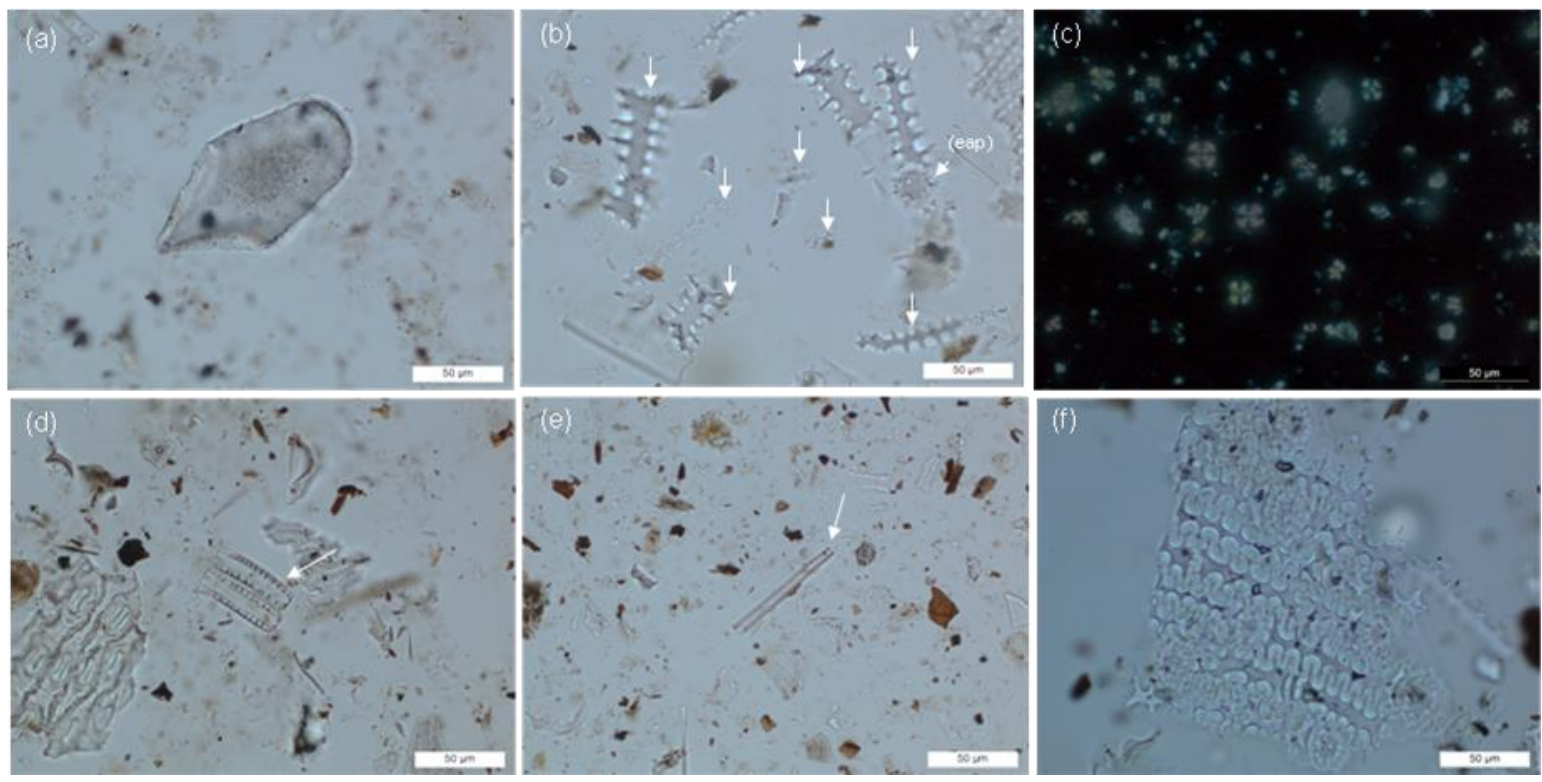

Figure 10. Photomicrographs of phytoliths and other microfossils identified in the samples (400×). (a) bulliform cell, sample PB-1; (b) dendritic long cells (arrows lcd) and epidermal appendage papillae (eap) from the inflorescence of grasses, $\mathrm{CH}-1$; (c) calcitic dung spherulites (XPL), PB-3; (d) diatoms, BK-7; (e) sponge spicule, BK-8; (f) multicellular structure of dendritic long cells with papillae from the husk of grasses, CH-1.

\section{Microfossil variations by context}

This section examines the variations noted in all the microfossil assemblages reported above considering, in particular, the depositional contexts of the samples for each of the investigated sites. However, in addition to the two types of microfossils that are the focus of this study, specifically phytoliths and calcitic spherulites, other types of silica biogenic components including diatoms and, to a lesser extent, sponge spicules, have been detected in multiple phytolith slides (Figure 10d-e). Diatoms are found in fresh or salt water, and in almost any context with a minimum moisture level (i.e. deposits, soils, building materials), and although they are also commonly present in dung, as demonstrated in many geo-ethnoarchaeological studies (Brochier et al. 1992; Portillo, 
Valenzuela, and Albert 2012; Portillo et al. 2014), this proxy has not been included in this study.

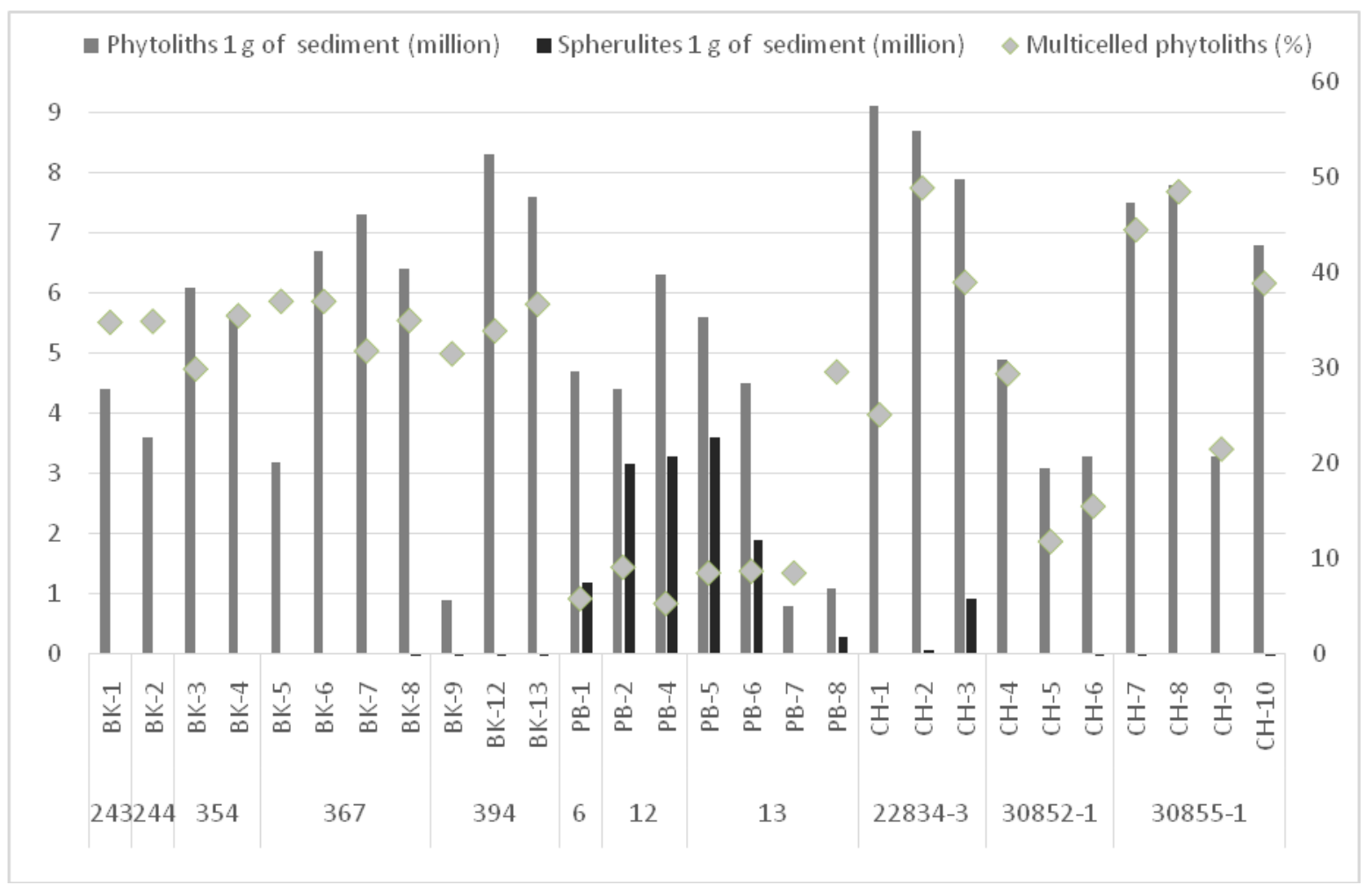

Figure 11. Plot showing absolute concentrations of phytoliths vs. dung spherulites in Boncuklu (BK), Pınarbaşı (PB) and Çatalhöyük (CH) samples, and percentages of multicelled phytoliths (grey diamonds, \% secondary axis).

This study has documented the occurrence of abundant phytolith microfossils in all Boncuklu samples, with several suspected omnivore coprolite samples displaying considerably lower numbers (Samples BK-1, BK-2, BK-5 and BK-9, Figure 11). Dung spherulites have been detected in substantially lower quantities, appearing to be completely absent in some of the samples from this site. Micromorphological results point towards the excellent preservation of coprolites in this context, likely in primary deposition and rapidly buried under relatively dry conditions, as suggested by the high degree of integrity, sharp edges, and strong parallel orientation of these discrete aggregates. Therefore, the scarcity of spherulites, often referred to as dung proxies (Canti 1999), could be due to the species responsible for the deposition of these 
remains. Previous studies have shown that the production of these calcitic bodies in the digestive tract is variable between species and partly dependent on diet (Canti 1997, 1998; Shahack-Gross 2011), with human and other omnivore animals producing the lowest amounts of spherulites in their faeces, although the mechanisms involved in spherulite production are not yet fully understood (Lancelotti and Madella 2012). The highest phytolith count has been found in the ashy midden samples, whereas coprolites appear to have very variable phytolith counts, possibly an effect of diet or, in some cases, post-depositional mixing of components in some layers caused by bioturbation, as observed through micromorphology. The leaves and culms of Pooideae grasses reeds and sedges dominate the phytolith record. Phytoliths derived from the floral parts of plants were abundant in specific samples (up to $30 \%$ of all the grass morphotypes in BK-3 and BK-5). Overall, the majority of phytoliths in these assemblages have been observed to derive from wild grasses and common reeds (Phragmites sp.) which, in addition to sedges, are frequently found in wetland environments. Additional wetland indicators such as diatoms and sponge spicules are also common in these deposits (Figure 10d-e).

In contrast, the Pınarbaşı assemblage displays larger, and less variable amounts of grass phytoliths in association with abundant dung spherulites. These are suggested to derive from ruminant faecal matter, particularly ovicaprines, as faunal remains from this site include a substantial proportion of herded sheep (Baird et al. 2011). In addition, modern reference livestock dung datasets from Mediterranean areas have demonstrated that sheep and goats are prolific producers of dung spherulites (Portillo, Valenzuela, and Albert 2012; Portillo et al. 2014; Portillo et al. 2017). The dominant morphotypes in this assemblage are individual or single-celled phytoliths, mainly epidermal short cells, which are produced in the leaves, culms, and inflorescences of 
grasses. The presence of short cells has been observed to account for ca. $40 \%$ of all grasses (Figure 10b). These belong mainly to the Pooideae subfamily, common in wellwatered environments. The occurrence of multicellular phytoliths from the leaves and culms of reeds has also been noted, but to a lesser extent (up to 5\%) than in most of the Boncuklu and Çatalhöyük contexts here described. Diatoms and sponge spicules are also present in most of the samples. Overall, micromorphological observations, together with phytolith and spherulite associations, appear to indicate that grasses were deposited at Pınarbaşı as part of herbivore dung and its sub-products, such as dung ashes derived from the use of these materials as fuel, a practice that seems to have been recurrent at this campsite.

Similarly to the Boncuklu contexts, the deposits studied from the nearby site of Çatalhöyük show large concentrations of phytoliths from grasses, reeds, and sedges in association with a relatively low spherulite content, especially in samples $\mathrm{CH} 4$ to $\mathrm{CH} 6$. This scarcity of dung indicators in Late Neolithic open contexts at Çatalhöyük was also observed during the micromorphological analysis of these in situ sequences. Only one of the Çatalhöyük samples displays moderate amounts of spherulites, suggesting the occurrence of accumulations of herbivore faecal matter in these layers ( $\mathrm{CH}-3$, Table 2), observed in thin-section to consist of highly burned dung used as fuel. In addition, this particular sample contains a comparatively high amount of short cells produced by Pooideae grasses, likely derived from dung matter. Also of significance in the Çatalhöyük assemblage is the presence of phytoliths derived from the floral parts of plants, comprising around $30 \%$ or more of the total number of grasses in most of the samples (Figure 9b). These were overwhelmingly high in sample $\mathrm{CH}-1$, and appear to derive from the husks of cereals such as wheat (around 72\%, Figure 10b-f). However, the complete absence of dung indicators in this particular layer and associated contexts, 
as determined through micromorphology, excludes the interpretation of this deposit as resulting from the use of cereal husks as fodder. In fact, the accumulation of husk materials in these contexts might be related to the performance of a varied range of domestic activities in this open location, such as cereal processing and subsequent burning of plant matter in open fires, which could potentially constitute a seasonality indicator. However, the well-documented practice of storage at Neolithic Çatalhöyük entails that plant material collected at any season could have been stored for later use in a different season of the year, thus hindering the use of plant domesticates as proxies for the investigation of seasonal activities at this site.

\section{Discussion and Conclusions}

This study has contributed to the investigation of formation processes in open spaces at the Neolithic sites of Boncuklu, Pınarbaşı and Çatalhöyük, illustrating the variability of coprolite inclusions found in these contexts and the complexity of human-animal interrelations during this period. Integrated micromorphological and microfossil observations have resulted in the identification of intact midden layers containing abundant faecal aggregates at Boncuklu, re-deposited units of burned dung at Pınarbaş1, and in situ combustion of plant materials and mixed fuels in Late Neolithic open spaces at Çatalhöyük, where faecal matter is scarce. The implications of these results for Neolithic economy and palaeoenvironment are discussed in more detail below.

\section{Identification of animal coprolites in Neolithic middens}

As several authors have pointed out (Kühn et al. 2013; Linseele et al. 2013), the optical appearance of coprolitic materials at the macro- and micro-scales can be highly variable, making it difficult to securely identify faecal matter in the archaeological record. Macroscopically, suspected coprolite inclusions and deposits were identified in 
the field at the three study sites mainly by colour - discrete orange aggregates corresponding to suspected omnivore coprolites and pale yellowish brown non-discrete deposits and lenses as suspected herbivore dung - and observed inclusions such as phytoliths and bones. However, this sampling strategy led to the misidentification, in some cases, of clay and mudbrick fragments as potential omnivore coprolites in Late Neolithic middens at Çatalhöyük, as concluded by the micromorphological analysis. Similarly, discarded fuel layers formed by siliceous plant remains and re-deposited sediment aggregates, some of which were initially suspected to contain herbivore dung, have shown very few faecal indicators at this site. These limitations highlight the importance of an integrated methodological approach for the correct interpretation of these open sequences.

In thin-section, diagnostic features of coprolites include morphology, which can range from sub-rounded pellets to amorphous or compressed phosphatic aggregates; groundmass characterisations; contextual associations within and between units; and the presence of specific components, such as bone fragments, phytoliths and spherulites, the latter being particularly useful for the detection of herbivore dung (Brönnimann et al. 2017a, 2017b ; Canti 1997). Coprolites at Boncuklu, which display a very low spherulite content and a highly variable proportion of phytoliths and digested bone remains, possibly reflecting differences in diet and feeding habits between individuals, have been classified as omnivore, although species determination is not possible with these techniques due to the similarities frequently displayed by pig, dog, and human excrements (Courty et al. 1989; Macphail and Goldberg 2010). Meanwhile, the faecal aggregates detected at Pınarbaşı, which display abundant embedded phytolith and spherulite microfossils, have been interpreted as ruminant dung, likely sheep, as 
inferred from the faunal assemblage in association to the occurrence of high concentrations of faecal spherulites (Canti 1999).

However, the nature of faecal remains varies not only according to diet, but to a number of other factors that include seasonality, age, depositional context, and taphonomic alterations (Brochier et al. 1992). In this regard, it is important to notice that herbivore dung at Pınarbaşı has been systematically identified in discarded fuel materials, either calcined or highly charred. Faecal spherulites disintegrate at temperatures of approximately $650-700^{\circ} \mathrm{C}$ (Matthews 2010; Shahack-Gross 2011), while siliceous plant remains melt at temperatures $\sim 850^{\circ} \mathrm{C}$ when fluxes such as alkali salts are present (Canti 2003). Similarly, faecal spherulites begin to degrade in a $\mathrm{pH} \leq 7$ in the presence of water, and dissolve rapidly in more acidic burial environments (Canti 1999; Canti and Brochier 2017), whereas phytoliths do not survive well in alkaline soils with a $\mathrm{pH}$ above 8.5 (Piperno 2006). Therefore, the excellent preservation of these two types of microfossils at Pınarbaşı is indicative of low/moderate firing temperatures and, more significantly, rapid burial at this campsite. Further, the ubiquitous presence of calcitic ashes in these deposits, which display little signs of alterations, seems again to suggest rapid disposal and/or burial of used fuel at Pınarbaşı (Mallol et al. 2007).

Nevertheless, although the integrated microscopic approach to Neolithic open spaces of this study has proven successful in determining the presence and type of faecal matter occurring in these sequences through the combination of qualitative micro-contextual observations of key deposits and quantitative phytolith and spherulite data, species determination of omnivore coprolites remains obscure. Preliminary biomolecular results from suspected omnivore faecal aggregates at Boncuklu have concluded that these are human coprolites, as indicated by the high content of coprostanol in the samples (I. Bull, pers. comm.). Future analyses of lipid biomarkers 
on these materials are expected to shed light on the origin of these coprolites in order to distinguish between human and animal waste, an aspect that is essential to enable further investigations of health, diet, and animal management at these Neolithic sites.

\section{Early husbandry practices in the Konya Plain}

Although in situ pen deposits in open areas have not been identified in any of the samples from the three study sites analysed in this research, zones of waste disposal and discarded dung fuel have been extensively documented in the stratigraphic sequences examined.

Area $\mathrm{M}$ at Boncuklu displays a high concentration of distinct, sub-rounded faecal pellets rich in bone fragments showing no trampling or compaction indicators. Although preliminary biomolecular analyses of these coprolites point towards the use of this open space as a latrine, the absence of penning contexts at this early agricultural settlement is not surprising considering that most of the species represented in the faunal assemblage were probably hunted, especially the predominant Bos and Sus (Baird et al. 2012; 2018). However, Baird et al. (2018) have recently suggested, based on bone isotope data, that caprine livestock may have been herded and kept close to the site, albeit in very small numbers. Micromorphological observations of external hearth sequences have detected the occurrence of charred herbivore dung aggregates in these contexts, although in very low proportions (García-Suárez et al. Forthcoming). This evidence suggests that the people at Boncuklu could have collected animal dung from the landscape for its occasional use as fuel, as penning deposits have not been observed to occur at this site. Aurochs, and possibly caprines, are the most likely species for the origin of the herbivore faecal materials found within hearths. 
Midden sequences at Pınarbaşı are characterised by very high percentages $(>50 \%)$ of re-deposited herbivore dung, most of which is charred or calcined. The composition of midden layers at this site suggests episodic nature of deposition, specifically related to burning and massive dumping. Penning areas have not been identified anywhere on site, in spite of the periodical use of the rockshelter as a hunting/herding locality in the $7^{\text {th }}$ millennium (Baird et al. 2011), although the collection of animal dung to use as fuel and the extensive reworking and postdepositional alterations affecting the site, including bioturbation and gypsum recrystallisation, could be partly responsible for this.

By contrast, the low content of faecal matter in Late Neolithic open spaces at Çatalhöyük observed in this research appears to be in line with the microstratigraphic evidence gathered in previous studies of middens at this site (Shillito 2011a), which have stressed the ashy nature of these deposits. In fact, the latest GDN and TPC middens, lying immediately below topsoil, are characterised by finely stratified sequences of recurrent ash layers representing in situ burning of plant fuel, largely grass/reed derived, as revealed during the micromorphological and phytolith analyses of these deposits. However, the identification of calcareous spherulites in samples $\mathrm{CH}-2$ and $\mathrm{CH}-3$ shows that herbivore dung was also occasionally burnt as fuel in these open areas, possibly related to the performance of specific activities in these spaces, such as the manufacture of architectural materials.

Shillito et al. (2011a) in their study of faecal biomarkers from suspected coprolites in midden, burial, and room fill contexts at Çatalhöyük, noted the relative absence of ruminant faeces in the assemblage, dominated by human coprolites. This pattern could be indicative that animals were kept away from the site, at least during the Late Neolithic period, possibly taken to pastures situated a few kilometres away from 
the settlement (Henton 2012). This ecological strategy would have entailed a significant increase in the mobility of humans and animals in the later levels of occupation at Çatalhöyük East, involving a drastic decrease in the amount of dung that was being discarded and burnt in open areas. This hypothesis has already been suggested by other specialists based on skeletal, faunal, and isotopic evidence from the later levels of occupation at Çatalhöyük East, which appear to indicate increased exploitation of the wider landscape during this period (Spencer Larsen et al. 2013; Pearson 2013; Russell et al. 2013).

In light of this evidence it would be tempting to hypothesise, based on the environmental model proposed by Roberts and Rosen (2009) involving a large nucleated settlement with fission and fusion of population aimed at exploiting a wide landscape region, that Pınarbaşı could have been regularly visited by task groups from Çatalhöyük focused on pastoral activities, a possibility already suggested by Baird et al. (2011). Although it is impossible to test this hypothesis solely based on microstratigraphic data, the evidence for increased mobility in the later levels of occupation of the East Mound, in addition to the apparent absence of herbivore dung in the late midden areas sampled at Çatalhöyük and the ubiquity of these remains at Pınarbaşı, appear to support this model.

\section{Palaeoenvironmental interpretations}

The microfossil data from coprolites and associated deposits reported here have provided further insights into landscape use and diets at the study sites. At Boncuklu, located on the periphery of the Çarşamba fan today, the abundance of Pooideae wild grasses, reeds and sedges in the phytolith record, particularly Phragmites sp., point to the intensive exploitation of local wetland environments by this community. 
Associations of diatoms and sponge spicules, indicative of well-watered conditions, are also common in these deposits.

Similarly, the leaves and culms of reeds and grasses, suggested to derive from fodder and herbivore dung, dominate the $7^{\text {th }}$ millennium phytolith assemblage at Pınarbaşı. These belong to the Pooideae subfamily, common in well-watered environments that, together with the occurrence of diatoms and sponge spicules, are again indicative of the recurrent exploitation of local marshland to the north and west of the site for pasturelands. However, the common occurrence of wood charcoal associated with discarded dung fuel deposits also point towards the collection of woods growing on the hills surrounding the site by this period (Asouti 2003).

In contrast, the husk of cereals, as well as the leaves and stems of grasses, reeds and sedges, constitute the phytolith assemblage recovered from Late Neolithic middens at Çatalhöyük. These highly articulated plant remains commonly display strong parallel orientations indicative of in situ organic decay. However, due to the general lack of dung materials in these deposits, these plant microfossils cannot be interpreted as evidence of diet but of preferred fuel sources for open fires, in particular mixed fuels formed by crop waste and wild grasses and sedges likely collected from the vicinity of the site. Ongoing microstratigraphic work on $7^{\text {th }}$ millennium open areas from Çatalhöyük, including an assessment of morphological and compositional changes affecting various types of faecal matter as a result of exposure to fire, is expected to contribute further to our current understanding of animal management and waste disposal in the latest levels of occupation of the East Mound.

\section{Acknowledgements}

This research was developed within the framework of the Çatalhöyük Research Project and the Boncuklu Project, and it was supported by an Arts and Humanities Research 
Council (AHRC) doctoral grant and a British Institute of Archaeology at Ankara (BIAA) study grant awarded to AGS. MP's research received funding from the European Union's Horizon 2020 Research and InnovationPprogramme under the Marie Sklodowska-Curie grant agreement No H2020-MSCA-IF-2015-702529. We would like to thank Douglas Baird and two anonymous reviewers for providing useful comments and suggestions on a draft of this paper. Special thanks are due to Sarah Lambert-Gates for helping with the production of the figures. We are also grateful to Douglas Baird, Ian Hodder, Arkadiusz Marciniak, and Marek Z. Barański for sampling permissions and their support with this research.

\section{References}

Akeret, Ö., and P. Rentzel. 2001. "Micromorphology and plant macrofossil analysis of cattle dung from the Neolithic lake shore settlement of Arbon Bleiche 3." Geoarchaeology 16 (6):687-700. doi: 10.1002/gea.1016.

Albert R. M., J. A. Ruiz, and A. Sans. 2016. "PhytCore ODB: a new tool to improve efficiency in the management and exchange of information on phytoliths." Journal of Archaeological Science 68: 98-105.

Albert, R. M., X. Esteve, M. Portillo, A. Rodríguez-Cintas, D. Cabanes, I. Esteban, and F. Hernández. 2011. "Phytolith CoRe, Phytolith Reference Collection." Accessed September 18, 2017. http://www.phytcore.org/phytolith/index.php

Albert, R. M., and S. Weiner. 2001. "Study of phytoliths in prehistoric ash layers from Kebara and Tabun caves using a quantitative approach." In Phytoliths: Applications in Earth Sciences and Human History, edited by J. D. Meunier and F. Colin, 251-66. Lisse: Balkema.

Albert, R. M., R. Shahack-Gross, D. Cabanes, A. Gilboa, S. Lev-Yadun, M. Portillo, I. Sharon, E. Boaretto, and S. Weiner. 2008. "Phytolith-rich layers from the Late Bronze and Iron Ages at Tel Dor (Israel): mode of formation and archaeological significance." Journal of Archaeological Science 35 (1):57-75. doi: http://dx.doi.org/10.1016/j.jas.2007.02.015.

Asouti, E. 2003. "Woodland vegetation and fuel exploitation at the prehistoric campsite of Pinarbasi, south-central Anatolia, Turkey: the evidence from the wood charcoal macro-remains." Journal of Archaeological Science 30:1185-201.

2005. "Woodland vegetation and the exploitation of fuel and timber at Neolithic Çatalhöyük: report on the wood-charcoal macro-remains." In 
Inhabiting Çatalhöyük: Reports from the 1995-1999 Seasons, edited by Ian Hodder, 213-58. Cambridge: McDonald Institute for Archaeological Research.

Baird, D. 1996. "The Konya Plain survey: aims and methods." In On the Surface: Çatalhöyük 1993-95, edited by Ian Hodder, 41-6. Cambridge: McDonald Institute for Archaeological Research.

2005. "The history of settlement and social landscape in the Early Holocene in the Çatalhöyük area." In Çatalhöyük Perspectives: Reports from the 1995-1999 Seasons, edited by Ian Hodder, 55-74. Cambridge: McDonald Institute for Archaeological Research.

. 2012. "The Late Epipaleolithic, Neolithic and Chalcolithic of the Anatolian Plateau, 13,000-4,000 BC." In A Companion to the Archaeology of the Ancient Near East, Volume I, edited by D. T. Potts, 431-65. Hoboken, NJ, USA: WileyBlackwell.

Baird, D., E. Asouti, L. Astruc, A. Baysal, E. Baysal, D. Carruthers, A. Fairbairn. 2013. "Juniper smoke, skulls and wolves' tails. The Epipalaeolithic of the Anatolian plateau in its South-west Asian context; insights from Pınarbaşı." Levant 45 (2):175-209. doi: 10.1179/0075891413Z.00000000024.

Baird, D., A. Fairbairn, O. Bar-Yosef, and G. Mustafaoğlu. 2013. "The Boncuklu Project: the spread of farming and the antecedents of Çatalhöyük." Heritage Turkey 3:21-3.

Baird, D., D. Carruthers, A. Fairbairn, and J. Pearson. 2011. "Ritual in the landscape: evidence from Pınarbaşı in the seventh-millennium cal BC Konya Plain." Antiquity 85:380-94.

Baird, D., A. Fairbairn, E. Jenkins, L. Martin, C. Middleton, J. Pearson, E. Asouti, Y. Edwards, C. Kabukcu, G. Mustafaoğlu, N. Russell, O. Bar-Yosef, G. Jacobsen, X. Wu, A. Baker, S. Elliott. 2018. "Agricultural origins on the Anatolian Plateau." Proceedings of the National Academy of Sciences. doi: https://doi.org/10.1073/pnas.1800163115.

Baird, D., A. Fairbairn, L. Martin, and C. Middleton. 2012. "The Boncuklu Project; the origins of sedentism, cultivation and herding in central Anatolia." In Neolithic in Turkey: New Excavations, New Discoveries, edited by M Ozdoğan and N Başgelen, 219-244. Istanbul: Arkeoloji ve Sanat Yayınları.

Barański, M. Z. 2013. "Back to Mellaart A Area: survey on Late Neolithic architecture." Çatalhöyük Archive Report:220-34.

. 2014. "Late Neolithic Architecture." Çatalhöyük Archive Report:194-202.

Barański, M. Z., A. García-Suárez, A. Klimowicz, S. Love, and K. Pawłowska. 2015. "The architecture of Neolithic Çatalhöyük as a process." In Assembling Çatalhöyük, edited by Ian Hodder and Arkadiusz Marciniak, 111-26. Leeds: Maney Publishing. 
Bayliss, A., F. Brock, S. Farid, I. Hodder, J. Southon, and R. E. Taylor. 2015. "Getting to the Bottom of It All: A Bayesian Approach to Dating the Start of Çatalhöyük." Journal of World Prehistory 28 (1):1-26. doi: 10.1007/s10963015-9083-7.

Boyer, P., N. Roberts, and D. Baird. 2006. "Holocene environment and settlement on the Çarşamba alluvial fan, south-central Turkey: Integrating geoarchaeology and archaeological field survey." Geoarchaeology 21 (7):675-98. doi: 10.1002/gea.20133.

Brochier, J. E., P. Villa, M. Giacomarra, and A. Tagliacozzo. 1992. "Shepherds and sediments: Geo-ethnoarchaeology of pastoral sites." Journal of Anthropological Archaeology 11 (1):47-102. doi: http://dx.doi.org/10.1016/0278-4165(92)90010$\underline{9}$.

Brönnimann, D., K. Ismail-Meyer, P. Rentzel, C. Pümpin, and L. Lisá. 2017a. "Excrements of herbivores." In Archaeological Soil and Sediment Micromorphology, edited by Cristiano Nicosia and Georges Stoops, 55-66. Chichester: John Wiley \& Sons.

Brönnimann, D., C. Pümpin, K. Ismail-Meyer, P. Rentzel, and N. Égüez. 2017b. "Excrements of omnivores and carnivores." In Archaeological Soil and Sediment Micromorphology, edited by Cristiano Nicosia and Georges Stoops, 67-82. Chichester: John Wiley \& Sons.

Brown, D. A. 1984. "Prospects and limits of a phytolith key for grasses in the central United States." Journal of Archaeological Science 11 (4):345-68. doi: https://doi.org/10.1016/0305-4403(84)90016-5.

Cabanes, D., R. Shahack-Gross. 2015. "Understanding fossil phytolith preservation: the role of partial dissolution in paleoecology and archaeology." PLOS ONE 10 (5): e0125532. doi: https://doi.org/10.1371/journal.pone.0125532

Cabanes, D., S. Weiner, R. Shahack-Gross. 2011. "Stability of phytoliths in the archaeological record: a dissolution study of modern and fossil phytoliths." Journal of Archaeological Science 38: 2480-2490.

Canti, M. G. 1997. "An investigation of microscopic calcareous spherulites from herbivore dungs." Journal of Archaeological Science 24 (3):219-31. doi: http://dx.doi.org/10.1006/jasc.1996.0105.

1998. "The micromorphological identification of faecal spherulites from archaeological and modern materials." Journal of Archaeological Science 25 (5):435-44. doi: http://dx.doi.org/10.1006/jasc.1997.0210.

1999. "The production and preservation of faecal spherulites: animals, environment and taphonomy." Journal of Archaeological Science 26 (3):251-8. doi: http://dx.doi.org/10.1006/jasc.1998.0322. 
- 2003. "Aspects of the chemical and microscopic characteristics of plant ashes found in archaeological soils." CATENA 54 (3):339-61. doi: http://dx.doi.org/10.1016/S0341-8162(03)00127-9.

Canti, M. G., and J. E. Brochier. 2017. "Faecal spherulites." In Archaeological Soil and Sediment Micromorphology, edited by Cristiano Nicosia and Georges Stoops, 51-54. Chichester: John Wiley \& Sons.

Canti, M. G., and C. Nicosia. 2018. "Formation, morphology and interpretation of darkened faecal spherulites." Journal of Archaeological Science 89: 32-45.

Courty, M. -A., P. Goldberg, and R. I. Macphail. 1989. Soils and Micromorphology in Archaeology. Cambridge: Cambridge University Press.

Driessen, P. M., and T. D. de Meester. 1969. Soils of the Çumra Area, Turkey, Agricultural Research Reports 720. Wageningen: Centre for Agricultural Publishing and Documentation.

Elliott, S., R. Bendrey, J. Whitlam, K. Rauf Aziz, and J. Evans. 2015. "Preliminary ethnoarchaeological research on modern animal husbandry in Bestansur, Iraqi Kurdistan: Integrating animal, plant and environmental data." Environmental Archaeology 20 (3):283-303. doi: 10.1179/1749631414Y.0000000025.

García-Suárez, A., R. Goodyear, J. Rowe, M. Portillo and W. Matthews. Forthcoming. "Microcontextual analyses of houses and open areas: insights into ecology and society at the Early Neolithic site of Boncuklu, Turkey." In Boncuklu: First Farmers in Central Anatolia and the Antecedents of Çatalhöyü , edited by Douglas Baird. London: British Institute of Archaeology at Ankara.

Gur-Arieh, S., R. Shahack-Gross, A. M. Maeir, G. Lehmann, L. A. Hitchcock, and E. Boaretto. 2014. "The taphonomy and preservation of wood and dung ashes found in archaeological cooking installations: case studies from Iron Age Israel." Journal of Archaeological Science 46: 50-67.

Gur-Arieh, S., E. Mintz, E. Boaretto, R. Shahack-Gross. 2013. "An ethnoarchaeological study of cooking installations in rural Uzbekistan: development of a new method for identification of fuel sources." Journal of Archaeological Science 40: 43314347.

Henton, E. 2012. "The combined use of oxygen isotopes and microwear in sheep teeth to elucidate seasonal management of domestic herds: the case study of Çatalhöyük, Central Anatolia." Journal of Archaeological Science 39: 32643276.

Hodder, I. 2007. "Çatalhöyük in the Context of the Middle Eastern Neolithic." Annual Review of Anthropology 36:105-20. doi: 10.2307/25064947.

Inoue, K., M. Saito, and T. Naruse. 1998. "Physicochemical, mineralogical, and geochemical characteristics of lacustrine sediments of the Konya Basin, Turkey, and their significance in relation to climatic change." Geomorphology 23 (2-4): 229-43. doi: http://dx.doi.org/10.1016/S0169-555X(98)00006-3. 
Jenkins, E. L., 2009. "Phytolith taphonomy: a comparison of dry ashing and acid extraction on the breakdown of conjoined phytoliths formed in Triticum durum." Journal of Archaeological Science 36: 2402-2407.

Katz, O., D. Cabanes, S. Weiner, A. Maeir, E. Boaretto, and R. Shahack-Gross. 2010. "Rapid phytolith extraction for analysis of phytolith concentrations and assemblages during an excavation: An application at Tell es-Safi/Gath, Israel." Journal of Archaeological Science 37: 1557-1563.

Kühn, M., U. Maier, C. Herbig, K. Ismail-Meyer, M. Le Bailly, and L. Wick. 2013. "Methods for the examination of cattle, sheep and goat dung in prehistoric wetland settlements with examples of the sites Alleshausen-Täschenwiesen and Alleshausen-Grundwiesen (around cal 2900 BC) at Lake Federsee, south-west Germany." Environmental Archaeology 18 (1): 43-57. doi: 10.1179/1461410313Z.00000000017.

Kuzucuoğlu, C., R. Parish, and M. Karabiyikoglu. 1998. "The dune systems of the Konya Plain (Turkey): their relation to environmental changes in Central Anatolia during the Late Pleistocene and Holocene." Geomorphology 23 (2-4): 257-71. doi: http://dx.doi.org/10.1016/S0169-555X(98)00008-7.

Lancelotti, C. and M. Madella. 2012. "The 'invisible' product: developing markers for identifying dung in archaeological contexts". Journal of Archaeological Science 39: 953-963.

Linseele, V., H. Riemer, J. Baeten, D. De Vos, E. Marinova, and C. Ottoni. 2013. "Species identification of archaeological dung remains: A critical review of potential methods." Environmental Archaeology 18 (1): 5-17. doi: 10.1179/1461410313Z.00000000019.

Madella, M., A. Alexandre, and T. Ball. 2005. "International Code for Phytolith Nomenclature 1.0." Annals of Botany 96:253-60. doi: 10.1093/aob/mci172.

Madella, M., and C. Lancelotti. 2012. "Taphonomy and phytoliths: A user manual." Quaternary International 275: 76-83.

Mallol, C., F. W. Marlowe, B. M. Wood, and C. C. Porter. 2007. "Earth, wind, and fire: ethnoarchaeological signals of Hadza fires." Journal of Archaeological Science 34 (12):2035-52. doi: http://dx.doi.org/10.1016/j.jas.2007.02.002.

Macphail, R. I. and P. Goldberg. 2010. "Archaeological materials." In Interpretation of Micromorphological Features in Soils and Regoliths, edited by G. Stoops, V. Marcelino and F. Mees, 589-622. Amsterdam: Elsevier.

Marciniak, A. 2015. "A new perspective on the Central Anatolian Late Neolithic: the TPC Area excavations at Çatalhöyük East." In The Archaeology of Anatolia: Recent Discoveries (2011-2014) Volume I, edited by S.R. Steadman and Gregory McMahon, 6-25. Newcastle upon Tyne: Cambridge Scholars Publishing. 
Martin, L., N. Russell, and D. Carruthers. 2002. "Animal remains from the Central Anatolian Neolithic." In The Neolithic of Central Anatolia, edited by F. Gérard and L. Thissen, 193-216. Istanbul: Ege Yayinlari.

Matthews, W. 2005. "Micromorphological and microstratigraphic traces of uses and concepts of space." In Inhabiting Çatalhöyük: Reports from the 1995-1999 Seasons, edited by Ian Hodder, 355-98. Cambridge: McDonald Institute and British Institute of Archaeology at Ankara.

2010. "Geoarchaeology and taphonomy of plant remains and microarchaeological residues in early urban environments in the Ancient Near East." Quaternary International $214 \quad$ (1-2):98-113. doi: http://dx.doi.org/10.1016/j.quaint.2009.10.019.

Matthews, W., C. A. I. French, T. Lawrence, and D. Cutler. 1996. "Multiple surfaces: the micromorphology." In On the Surface: Çatalhöyük 1993-1995, edited by I. Hodder, 301-342. Cambridge: McDonald Institute for Archaeological Research and British Institute of Archaeology at Ankara.

Milek, K. 2012. Floor formation processes and the interpretation of activity areas: an ethnoarchaeological study of turf buildings at Thverá, northeast Iceland. Journal of Anthropological Archaeology 31: 119-137.

Mulholland, S. C. , and George Rapp. 1992. "A morphological classification of grass silica-bodies." In Phytolith Systematics, edited by George Jr. Rapp and Susan C. Mulholland, 65-89. New York: Plenum Press.

Özdoğan, M. . 1999. "Concluding remarks." In Neolithic in Turkey: The Cradle of Civilization / New Discoveries, edited by M. Özdoğan and N. Başgelen, 22536. Istanbul: Arkeoloji ve Sanat Yayınları.

Özkan, H., A. Brandolini, R. Schäfer-Pregl and F. Salamini. 2002. "AFLP Analysis of a collection of tetraploid wheats indicates the origin of emmer and hard wheat domestication in Southeast Turkey." Molecular Biology and Evolution 19: 17971801 .

Pearson, J. A. 2013. "Human and animal diet as evidenced by stable carbon and nitrogen isotope analysis." In Humans and Landscapes of Çatalhöyük: Reports from the 2000-2008 Seasons, edited by Ian Hodder, 271-98. London and Los Angeles: British Institute at Ankara \& Cotsen Institute of Archaeology Press.

Piperno, D. R. 2006. Phytoliths. A Comprehensive Guide for Archaeologists and Paleoecologists. Oxford: AltaMira Press.

Portillo, M., M. C. Belarte, J. Ramon, N. Kallala, J. Sanmartí, and R. M. Albert. 2017. "An ethnoarchaeological study of livestock dung fuels from cooking installations in northern Tunisia." Quaternary International 431:133-44. doi: http://dx.doi.org/10.1016/j.quaint.2015.12.040.

Portillo, M., S. Kadowaki, Y. Nishiaki, and R. M. Albert. 2014. "Early Neolithic household behavior at Tell Seker al-Aheimar (Upper Khabur, Syria): a 
comparison to ethnoarchaeological study of phytoliths and dung spherulites." Journal of Archaeological Science 42 (Supplement C):107-18. doi: https://doi.org/10.1016/j.jas.2013.10.038.

Portillo, M., S. Valenzuela, and R. M. Albert. 2012. "Domestic patterns in the Numidian site of Althiburos (northern Tunisia): The results from a combined study of animal bones, dung and plant remains." Quaternary International 275 (0):8496. doi: http://dx.doi.org/10.1016/j.quaint.2012.01.024.

Rentzel, P., C. Nicosia, A. Gebhardt, D. Brönnimann, C. Pümpin, and K. Ismail-Meyer. 2017. "Trampling, poaching and the effect of traffic." In Archaeological Soil and Sediment Micromorphology, edited by Cristiano Nicosia and Georges Stoops, 281-297. Chichester: John Wiley \& Sons.

Roberts, N., S. Black, P. Boyer, W. J. Eastwood, H. I. Griffiths, H. F. Lamb, M. J. Leng, et al. 1999. "Chronology and stratigraphy of Late Quaternary sediments in the Konya Basin, Turkey: Results from the KOPAL Project." Quaternary Science Reviews 18 (4-5):611-30. doi: http://dx.doi.org/10.1016/S02773791(98)00100-0.

Roberts, N., and A. M. Rosen. 2009. "Diversity and complexity in early farming communities of Southwest Asia: new insights into the economic and environmental basis of Neolithic Çatalhöyük." Current Anthropology 50 (3):393-402.

Rosen, A. M. 1992. "Preliminary identification of silica skeletons from Near Eastern archaeological sites: an anatomical approach." In Phytolith Systematics edited by George Rapp and Susan C. Mulholland, 129-48. New York: Plenum Press.

Russell, N., K. C. Twiss, D. C. Orton, and G. Arzu Demirergi. 2013. "More on the Çatalhöyük mammal remains." In Humans and Landscapes of Çatalhöyük: Reports from the 2000-2008 Seasons, edited by Ian Hodder, 213-58. London and Los Angeles: British Institute at Ankara and Cotsen Institute of Archaeology Press.

Shahack-Gross, R. 2011. "Herbivorous livestock dung: formation, taphonomy, methods for identification, and archaeological significance." Journal of Archaeological Science 38 (2):205-18. doi: http://dx.doi.org/10.1016/j.jas.2010.09.019.

2017. "Animal gathering enclosures". In Archaeological Soil and Sediment Micromorphology, edited by Cristiano Nicosia and Georges Stoops, 265-280. Chichester: John Wiley \& Sons.

Shahack-Gross, R., F. Marshall, K. Ryan, and S. Weiner. 2004. "Reconstruction of spatial organization in abandoned Maasai settlements: implications for site structure in the Pastoral Neolithic of East Africa." Journal of Archaeological Science 31 (10):1395-411. doi: http://dx.doi.org/10.1016/j.jas.2004.03.003.

Shillito, L.-M. 2011a. Daily Activities, Diet and Resource Use at Neolithic Çatalhöyük: Microstratigraphic and Biomolecular Evidence from Middens. Vol. BAR International Series 2232. Oxford: Archaeopress. 
2011b. "Taphonomic observations of archaeological wheat phytoliths from Neolithic Çatalhöyük, Turkey, and the use of conjoined phytolith size as an indicator of water availability." Archaeometry 53: 631-641.

Shillito, L.-M., I. D. Bull, W. Matthews, M. J. Almond, J. M. Williams, and R. P. Evershed. 2011. "Biomolecular and micromorphological analysis of suspected faecal deposits at Neolithic Çatalhöyük, Turkey." Journal of Archaeological Science 38 (8):1869-77. doi: http://dx.doi.org/10.1016/j.jas.2011.03.031.

Shillito, L.-M., and W. Matthews. 2013. "Geoarchaeological Investigations of MiddenFormation Processes in the Early to Late Ceramic Neolithic Levels at Çatalhöyük, Turkey ca. 8550-8370 cal BP." Geoarchaeology 28 (1):25-49. doi: 10.1002/gea.21427.

Spencer Larsen, C. , S. W. Hillson, C. B. Ruff, J. W. Sadvari, and E. M. Garofalo. 2013. "The human remains II: interpreting lifestyle and activity in Neolithic Çatalhöyük." In Humans and Landscapes of Çatalhöyük: Reports from the 2000-2008 Seasons, edited by Ian Hodder, 397-412. London and Los Angeles: British Institute at Ankara \& Cotsen Institute of Archaeology Press.

Stiner, M. C., H. Buitenhuis, G. Duru, S. L. Kuhn, S. M. Mentzer, N. D. Munro, N. Pöllath, J. Quade, G. Tsartsidou, and M. Özbaşaran. 2014. "A forager-herder trade-off, from broad-spectrum hunting to sheep management at Aşıklı Höyük, Turkey." Proceedings of the National Academy of Sciences 111 (23):8404-9. doi: 10.1073/pnas.1322723111.

Stoops, G. 2003. Guidelines for Analysis and Description of Soil and Regolith Thin Sections. Madison, Wisconsin: Soil Science Society of America.

Tsartsidou, G., S. Lev-Yadun, R.-M. Albert, A. Miller-Rosen, N. Efstratiou, and S. Weiner. 2007. "The phytolith archaeological record: strengths and weaknesses evaluated based on a quantitative modern reference collection from Greece." Journal of Archaeological Science 34 (8):1262-75. doi: http://dx.doi.org/10.1016/j.jas.2006.10.017.

Tsartsidou, G., S. Lev-Yadun, N. Efstratiou, and S. Weiner. 2008. "Ethnoarchaeological study of phytolith assemblages from an agro-pastoral village in Northern Greece (Sarakini): development and application of a Phytolith Difference Index." Journal of Archaeological Science 35 (3):600-13. doi: http://dx.doi.org/10.1016/j.jas.2007.05.008.

Twiss, P. C. . 1992. "Predicted world distribution of $\mathrm{C}_{3}$ and $\mathrm{C}_{4}$ grass phytoliths." In Phytolith Systematics, edited by George Rapp and Susan C. Mulholland, 113-28. New York: Plenum Press.

Twiss, P. C., C. E. Suess, and R. M. Smith. 1969. "Morphological classification of grass phytoliths." Soil Science Society of America Proceedings 33:109-15.

Watkins, T. 1996. "Excavations at Pinarbasi: the early stages." In On the Surface: Çatalhöyük 1993-95, edited by Ian Hodder, 47-58. Cambridge: McDonald Institute. 
Yeomans, L. 2005. "Discard and disposal practises at Çatalhöyük: a study through the characterisation of the faunal remains." In Inhabiting Çatalhöyük: Reports from the 1995-1999 Seasons, edited by Ian Hodder, 573-86. Cambridge: McDonald Institute. 